\title{
Twelve Months with COVID-19: What Gastroenterologists Need to Know
}

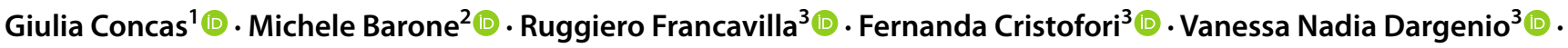

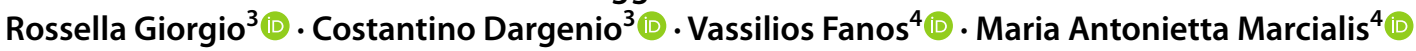

Received: 8 October 2020 / Accepted: 6 July 2021 / Published online: 31 July 2021

(c) The Author(s) 2021

\begin{abstract}
Corona virus disease-19 (COVID-19) is the latest global pandemic. COVID-19 is mainly transmitted through respiratory droplets and, apart from respiratory symptoms, patients often present with gastrointestinal symptoms and liver involvement. Given the high percentage of COVID-19 patients that present with gastrointestinal symptoms (GIS), in this review, we report a practical up-to-date reference for the physician in their clinical practice with patients affected by chronic gastrointestinal (GI) diseases (inflammatory bowel disease, coeliac disease, chronic liver disease) at the time of COVID-19. First, we summarised data on the origin and pathogenetic mechanism of SARS-CoV-2. Then, we performed a literature search up to December 2020 examining clinical manifestations of GI involvement. Next, we illustrated and summarised the most recent guidelines on how to adhere to GI procedures (endoscopy, liver biopsy, faecal transplantation), maintaining social distance and how to deal with immunosuppressive treatment. Finally, we focussed on some special conditions such as faecal-oral transmission and gut microbiota. The rapid accumulation of information relating to this condition makes it particularly essential to revise the literature to take account of the most recent publications for medical consultation and patient care.
\end{abstract}

Keywords COVID-19 · SARS-CoV-2 · Gastrointestinal symptoms · Inflammatory bowel disease $\cdot$ Coeliac disease $\cdot$ Liver diseases

\begin{tabular}{ll}
\multicolumn{2}{l}{ Abbreviations } \\
ACL & Acute-on-chronic liver \\
CLD & Chronic liver disease \\
ACE-2 & Angiotensin-converting enzyme 2 \\
CD & Coeliac disease \\
COVID-19 & Corona virus disease-19 \\
GI & Gastrointestinal \\
GIS & Gastrointestinal symptoms
\end{tabular}

Core tip: Gastrointestinal (GI) symptoms and liver involvement are present in about $20 \%$ of patients with COVID-19 and, when present, suggest progression towards a more critical illness. SARS$\mathrm{CoV}-2$ does not worsen the prognosis of pre-existing GI or liverrelated diseases, and specific guidelines have been addressed to face the problem. GI procedures must be performed in urgent cases and deferred whenever possible. The more prolonged survival of the virus in the faeces compared to the respiratory tract generates doubts about the appropriateness of the current discharge criteria. The relationship between gut microbiota, ACE-2 expression and the clinical course of COVID-19 still needs to be elucidated.

Michele Barone

michele.barone@uniba.it

Extended author information available on the last page of the article
IBD Inflammatory bowel disease

IL Interleukin

MERS Middle East respiratory syndrome

SARS-CoV Severe acute respiratory syndrome

\section{Origin and Pathogenetic Mechanism of SARS-CoV-2}

At the end of 2019, a new coronavirus named SARS-CoV-2 (severe acute respiratory syndrome) was isolated and the disease related to it was indicated by the acronym COVID-19 (corona virus disease-19). Human-to-human infection was first reported in the Huanan fish market in Wuhan, and then spread to China, leading to a global pandemic. According to the World Health Organization, as at December 31 2020, the pandemic has caused 95,321,880 infections worldwide and 2,058,227 deaths [1]. SARS-CoV-2 displayed partial similarity to SARS-CoV and MERS-CoV (Middle East respiratory syndrome) in phylogenetic research, clinical manifestations and pathological findings. Based on the genome sequence, SARSCoV-2 is approximately $89 \%$ identical to bat SARS-like-CoV, 
$82 \%$ identical to SARS-CoV human and $50 \%$ identical to MERS-CoV. Cases range across all ages, with most patients between 35 and 55 years and fewer cases among children and infants. Males are more susceptible than females (65\%) [2]. Symptoms may include fever, cough, sore throat, nausea, myalgia and mild flu-like symptoms; a small percentage evolve towards respiratory failure needing ventilatory support and, in the most severe cases, multi-organ failure and death [3].

Coronavirus spike surface glycoprotein (S-protein of SARSCoV-2) binds to angiotensin-converting enzyme 2 (ACE-2) to invade host cells. Through genomics studies, researchers have shown that SARS-CoV-2 binds to the same receptor with an affinity which is approximately 10 - to 20 -fold higher than SARS-CoV [4-6]. Many organs and tissues, besides the respiratory tract, have a high expression of ACE-2: heart, skin, kidney, endothelial cells of small and large vessels and fat. In the gastrointestinal tract, ACE- 2 is abundantly expressed at the oesophageal level and in the small and large intestine, particularly in the ileum [7-10]. From an evolutionary point of view, ACE-2 has high structural homology with collectrin, a transmembrane protein with a regulatory function in the expression of neutral amino-acid transporters at the brush border of the proximal renal tubules. The enzyme has a double function: a negative regulation on the renin-angiotensin-aldosterone system and an amino-acid transporter mainly in the small intestine. In the gut, collectrin is not expressed, and its role is performed by ACE-2, which acts as the chaperone for trafficking of an amino-acid transporter on cell membranes, B0AT1, which mediates uptake of neutral amino-acids into intestinal cells. Some studies have shown that ACE-2 knock-out mice do not express B0AT1 in the gut and have low levels of the aminoacids tryptophan, valine, threonine and tyrosine, resulting in severe intestinal inflammation and microbial imbalance. Structural modelling has suggested that the ACE2-B0AT1 complex can bind the S-protein of SARS-Cov-2 and that ACE-2 might be the viral entry point for SARS-CoV-2 in the gut [11].

This systematic review summarises a 1 -year experience in dealing with patients with COVID-19 and gastrointestinal symptoms (GIS) before the vaccination programme. We aim to highlight the prevalence and clinical significance of GIS in patients with COVID-19 and to report up-to-date, brief and practical information for gastroenterologists dealing with chronic gastrointestinal diseases (inflammatory bowel disease, coeliac disease, chronic liver disease) at the time of COVID-19.

\section{Clinical Studies Collection and Deriving Strategies}

We performed a literature search in December 2020, focussing on articles published from January 1 2020, examining data on clinical manifestations of gastrointestinal involvement. For this purpose, we performed an electronic search of the literature using the online databases Cochrane Library, PubMed, Scopus and Web of Science, entering the query terms ("SARS-CoV-2" OR "COVID-19") AND ("intestine*" OR "gastr*" OR "pancr*" OR "esopha*" OR "colon*" OR "rectum, "nausea" OR "vomit" OR "diarrhoea" OR "abdominal pain" OR "anorexia"). We eliminated a priori all experimental studies and limited our literature search to articles published in English in peer-reviewed journals. Further relevant articles were hand-searched using the references of the selected studies. Eligibility criteria were evaluations of in-patients with gastrointestinal symptoms.

\section{Gastrointestinal Involvement in Covid-19}

\section{Gastrointestinal Symptoms in Adults}

Due to the presence and function of ACE- 2 at the intestinal level, many authors have hypothesised that the virus may present a tropism for the enteric epithelium, causing GIS. Although initial studies indicated that GIS was not frequent in COVID-19, recent evidence has shown that this is not the case. In Table 1 and Table S1, respectively, all studies with more than 100 and less than 100 patients found by our systematic literature search are reported, describing the most frequent GIS: anorexia, diarrhoea, nausea, vomiting and abdominal pain [12-125]. A possible reason for the relatively high prevalence of diarrhoea compared to other GIS is that gut epithelial cells (especially in the ileum) have a significantly high ACE-2 expression. GIS might predispose to electrolyte disruptions, hyponatremia, which could exacerbate the disease.

A total of 318 patients with confirmed COVID-19 were included in a US multicentre cohort study. Overall, $61 \%$ of patients reported at least one GIS on admission, most specifically anorexia (35\%), diarrhoea (34\%) and nausea (26\%). In addition, patients with GIS reported higher levels of fatigue, myalgia and odour or taste loss. In this experience, there were no variations in clinical deterioration rates between patients with and without GIS when comparing admission to intensive care unit (ICU), mechanical ventilation needs or overall mortality possibly due to the absence of ICU rooms/ ventilators at the participating hospitals [25]. A recent paper reported a correlation between the presence of GIS and the severity of respiratory symptoms, the need for ventilatory support and ICU admission [126]. COVID-19 patients with GIS experience worse respiratory symptoms (higher rates of fever, shortness of breath and headache). Moreover, severe cases of COVID-19 occur frequently in patients with GIS, as compared to those without ( $23 \%$ vs. $8 \%$ ), consistent with the possibility that an intestinal localization might increase the release of pro-inflammatory cytokines with an impact 
Table 1 Studies with more than 100 cases reporting gastrointestinal in COVID-19 patients

\begin{tabular}{|c|c|c|c|c|c|c|c|}
\hline \multirow[t]{2}{*}{ Author } & \multirow[t]{2}{*}{ Patients $(n)$} & \multirow[t]{2}{*}{ Age (years) } & \multirow[t]{2}{*}{ Disease severity } & \multicolumn{4}{|c|}{ Gastrointestinal symptoms (\%) } \\
\hline & & & & Anorexia & Diarrhoea & Nausea/vomiting & Abdominal pain \\
\hline Wang et al. [12] & 138 & $56(22-92)$ & $\begin{array}{l}36 \text { ICU; } 102 \text { non- } \\
\text { ICU }\end{array}$ & $\begin{array}{l}\text { 66.7 ICU } \\
30.4 \text { non-ICU }\end{array}$ & $\begin{array}{l}\text { 16.7 ICU } \\
7.8 \text { non-ICU }\end{array}$ & $\begin{array}{l}8.3 \mathrm{ICU} \\
2.0 \text { non-ICU }\end{array}$ & $\begin{array}{l}8.3 \text { ICU } \\
0 \text { non-ICU }\end{array}$ \\
\hline Han et al. [13] & 108 & $45(21-90)$ & Mild & - & 14 & - & - \\
\hline Pan et al. [14] & 204 & $52.9 \pm 16$ & Mild to severe & 40 & 17 & $-/ 2$ & 1 \\
\hline $\begin{array}{l}\text { Cholankeril et al. } \\
\text { [15] }\end{array}$ & 116 & $50(35-67)$ & Mild to severe & 25.3 & 14.6 & 14.6 & 8.8 \\
\hline Guan et al. [16] & 1099 & $47(35-58)$ & Mild to severe & - & 3.8 & 5 & - \\
\hline Zhang et al. [17] & 115 & $49.5 \pm 17.1$ & Mild to severe & - & - & - & - \\
\hline Wang et al. [18] & 1012 & $50(39-58)$ & Mild to severe & - & 15 & 3.6 & 3.7 \\
\hline Chen et al. [19] & 249 & $51(36-64)$ & $\begin{array}{l}22 \text { ICU; } 227 \text { non- } \\
\text { ICU }\end{array}$ & $-; 3.2$ & $-; 3.2$ & - & - \\
\hline Liu et al. [20] & 137 & $55 \pm 16$ & - & - & 8 & - & - \\
\hline Zhou et al. [21] & 191 & $56(46-67)$ & - & - & 5 & 4 & - \\
\hline Zhou et al. [22] & 254 & $50(36-65)$ & Mild to severe & - & 18.1 & $5.9 / 8.3$ & 1.2 \\
\hline Guo et al. [23] & 174 & $59(49-67)$ & $\begin{array}{l}\text { Moderate to } \\
\text { severe }\end{array}$ & - & 12.1 & 9.8 & - \\
\hline Shi et al. [24] & 416 & $45(22-90)$ & $\begin{array}{l}\text { Moderate to } \\
\text { severe }\end{array}$ & - & 3.8 & - & - \\
\hline Redd et al. [25] & 318 & $63.4 \pm 16.6$ & Mild to severe & 34.8 & 33.7 & $26.4 / 15.4$ & 14.5 \\
\hline Jin et al. [26] & 651 & $46.14 \pm 14.19$ & $\begin{array}{l}\text { Moderate to } \\
\text { severe }\end{array}$ & - & 8.14 & $2.6 / 2.7$ & - \\
\hline Nobel et al. [27] & 278 & - & - & - & 20.1 & 22.7 & - \\
\hline $\begin{array}{l}\text { Klopfenstein et al. } \\
\text { [28] }\end{array}$ & 114 & $\begin{array}{l}56( \pm 18) \\
\text { (group of } \\
\text { patients with } \\
\text { diarrhoea) }\end{array}$ & - & - & 48 & $32.45 / 9.64$ & 22.8 \\
\hline $\begin{array}{l}\text { Cholankeril et al. } \\
\text { [29] }\end{array}$ & 207 & $49(34-65)$ & - & - & 10.8 & 10.8 & 7.1 \\
\hline Moura et al. [30] & 400 & $56.40(16.07)$ & $\begin{array}{l}\text { Moderate to } \\
\text { severe }\end{array}$ & 11.5 & 17.25 & $13.75 / 7.50$ & 6.00 \\
\hline Rao et al. [31] & 240 & $48(23-87)$ & $\begin{array}{l}\text { Moderate to } \\
\text { severe }\end{array}$ & - & 8.5 & 6.3 & - \\
\hline Du et al. [32] & 345 & $63.0(50.0-68.0)$ & Mild to critical & - & 21.2 & $7.0 / 5.2$ & 3.8 \\
\hline Jalali et al. [33] & 2322 & - & - & 2.1 & 3.6 & $5.2 / 3.5$ & 2.5 \\
\hline Khalil et al. [34] & 226 & $41.6 \pm 14.8$ & - & 44.7 & 35 & $22.6 /$ & - \\
\hline $\begin{array}{l}\text { Elmunzer et al. } \\
\text { [35] }\end{array}$ & 1992 & $60.1 \pm 16.3$ & - & - & 34 & $27 / 16$ & 11 \\
\hline $\begin{array}{l}\text { Laszkowska et al. } \\
\text { [36] }\end{array}$ & 2804 & $63.4 \pm 18.4$ & - & - & 23.4 & 23.2 & 11.9 \\
\hline Kang et al. [37] & 118 & $61.0(50-70)$ & - & - & 45.8 & - & - \\
\hline $\begin{array}{l}\text { Sulaiman et al. } \\
\text { [38] }\end{array}$ & 140 & $44.99 \pm 16.81$ & Mild to critical & 28.57 & 29.28 & 22.14 & 30 \\
\hline Livanos et al. [39] & 634 & $64 \pm 16$ & Mild to severe & - & 39 & $25 / 13$ & - \\
\hline Renelus et al. [40] & 734 & $66.1 \pm 15.6$ & - & - & 20.3 & $14.9 / 8.45$ & 9.26 \\
\hline $\begin{array}{l}\text { Bannaga et al. } \\
\text { [41] }\end{array}$ & 321 & $73(56.0-82.0)$ & - & - & 4 & 4.6 & 4.6 \\
\hline Lei et al. [42] & 115 & $66(60-70)$ & Mild to critical & 7.83 & 12.17 & 7.83 & - \\
\hline Ianiro et al. [43] & 420 & 61 & - & - & 37 & $19 /-$ & 14 \\
\hline $\begin{array}{l}\text { Hajifathalian et al. } \\
\text { [44] }\end{array}$ & 1059 & $61.1 \pm 18.3$ & - & 22.7 & 22.1 & $15.9 / 8.6$ & 6.8 \\
\hline Zhang et al. [45] & 505 & $51.2 \pm 17.2$ & Mild to severe & 18.4 & 12.3 & $5.3 / 2.6$ & 3.4 \\
\hline Aghemo et al. [46] & 292 & $65.0 \pm 14.1$ & - & - & 27.1 & -14.0 & - \\
\hline
\end{tabular}


Table 1 (continued)

\begin{tabular}{|c|c|c|c|c|c|c|c|}
\hline \multirow[t]{2}{*}{ Author } & \multirow[t]{2}{*}{ Patients $(n)$} & \multirow[t]{2}{*}{ Age (years) } & \multirow[t]{2}{*}{ Disease severity } & \multicolumn{4}{|c|}{ Gastrointestinal symptoms (\%) } \\
\hline & & & & Anorexia & Diarrhoea & Nausea/vomiting & Abdominal pain \\
\hline Chen et al. [47] & 101 & $48.32 \pm 14.74$ & Mild to moderate & 53 & 50 & $30 / 14$ & 26 \\
\hline Zhao et al. [48] & 401 & $47(33-60)^{\mathrm{b}}$ & Mild to critical & - & 6.2 & 0.2 & - \\
\hline Ferm et al. [49] & 892 & $59(47-72)$ & - & 11.8 & 19.8 & $16.6 / 10.2$ & 7.8 \\
\hline $\begin{array}{l}\text { Sierpiński et al. } \\
\text { [50] }\end{array}$ & 1942 & 50 & Mild to moderate & 47 & 24.2 & $-1-$ & - \\
\hline Cao et al. [51] & 157 & $49.3(14.5)$ & Severe: $26.1 \%$ & 29.9 & 15.9 & $13.4 /-$ & - \\
\hline $\begin{array}{l}\text { Annweiler et al. } \\
\text { [52] }\end{array}$ & 353 & $84.7 \pm 7.0$ & - & - & 21.8 & 6.2 & - \\
\hline Zhang et al. [53] & $\begin{array}{l}107 \text { patients With } \\
\text { cancer }\end{array}$ & $66(36-98)$ & Mild to severe & - & 14.0 & - & - \\
\hline Zhang et al. [54] & 409 & $65(56-71)$ & Severe & - & 22.2 & $12.2 / 10.3$ & 6.8 \\
\hline Khan et al. [55] & 122 & 49 & Mild to severe & - & 4.92 & $1.64 /-$ & - \\
\hline Zheng et al. [56] & 1320 & $50(40-57)$ & $\begin{array}{l}\text { Mild and common } \\
\text { type }\end{array}$ & 4.7 & 8.1 & 4.3 & 1.0 \\
\hline Luo et al. [57] & 1411 & $\begin{array}{l}\text { Initial gastroin- } \\
\text { testinal symp- } \\
\text { toms: } 53.8 \\
\text { Respiratory } \\
\text { syndrome and } \\
\text { fever: } 56.2\end{array}$ & - & 12.8 & 4.8 & $9.5 / 8.4$ & 4.6 \\
\hline $\begin{array}{l}\text { Kaafarani et al. } \\
\text { [58] }\end{array}$ & 141 & $57(47-70)$ & Severe & - & 29.8 & 22.0 & 14.9 \\
\hline Zhan et al. [59] & 405 & $56(17-95)$ & $\begin{array}{l}\text { Non-severe to } \\
\text { severe }\end{array}$ & 42 & 27.7 & 18.8 & 10.1 \\
\hline Díaz et al. [60] & 7016 & $39.79 \pm 20.6$ & ICU $28.4 \%$ & - & 7.3 & - & 3.7 \\
\hline $\begin{array}{l}\text { Bhayana et al. } \\
\text { [61] }\end{array}$ & 412 & $57(18-90)$ & ICU $33 \%$ & - & 4.8 & 7.1 & 33 \\
\hline $\begin{array}{l}\text { García-Azorín } \\
\text { et al. [62] }\end{array}$ & $\begin{array}{l}104 \text { with head- } \\
\text { ache }\end{array}$ & $56.7(11.2)$ & Mild to severe & - & 47.1 & 10.6 & - \\
\hline Sadeghi et al. [63] & 102 & $55.13 \pm 17.02$ & Non-ICU & - & 18.5 & - & - \\
\hline Chen et al. [64] & 369 & $61.0(50.0-70.0)$ & Mild to severe & - & 57.9 & 19.8 & 10.6 \\
\hline $\begin{array}{l}\text { Elimian et al. } \\
{[65]^{\mathrm{c}}}\end{array}$ & 10,517 & 35.6 & Mild to severe & - & 3.1 & $3 / 2$ & 0.3 \\
\hline Kim et al. [66] & 540 & $36(26-47)$ & Mild to severe & 12.5 & 5.8 & $5.3 / 3.9$ & 6.6 \\
\hline An et al. [67] & 205 & $54(22-77)$ & Mild to death & 28.8 & 9.8 & $5.9 / 2.9$ & 2 \\
\hline $\begin{array}{l}\text { Ganz-Lord et al. } \\
\text { [68] }\end{array}$ & 1698 & 43.91 & Mild to death & - & 36.7 & - & - \\
\hline $\begin{array}{l}\text { Alizadehsani et al. } \\
\text { [69] }\end{array}$ & 319 & $45.48 \pm 18.50$ & Mild to severe & 8.1 & - & - & - \\
\hline Jiang et al. [70] & 215 & $68 \pm 64,72$ & Mild to death & 26 & 12.6 & 5.1 & - \\
\hline & 66 & $84 \pm 81.85$ & & 43.9 & 3 & 9.1 & \\
\hline Jiang et al. [71] & 495 & $42.24 \pm 16: 99$ & Mild to severe & 1.4 & 7.07 & 5.85 & 2 \\
\hline
\end{tabular}

Age expressed as mean \pm standard deviation or median (range) or range

${ }^{a}$ Five paediatric cases

${ }^{\mathrm{b}} 30$ paediatric cases

${ }^{\mathrm{c}} 1268$ paediatric cases

on clinical outcome [49]. Wang et al. reported that, in ICU patients, the proportion of GIS, especially anorexia and abdominal pain, was higher than in non-ICU patients (anorexia $66.7 \%$ vs. $30.4 \%$; abdominal pain $8.3 \%$ vs. $0 \%$ ) [12].
Abdominal pain, although less frequent, has been associated with severe disease [127].

A recent meta-analysis showed that the prevalence of nausea and vomiting was 7\% (95\% CI 0.04-0.09), diarrhea was 
$8 \%$ (95\% CI 0.06-0.11), abdominal pain was 3\% (95\% CI $0.01-0.05)$ and anorexia was $17 \%$ (95\% CI 0.06-0.27) [128]. Thus, revaluation of GIS by SARS-COV-2 was lower than by SARS and MERS [129, 130]. Finally, with regard to GI involvement, critical intestinal ischemia has been recorded in $2-5 \%$ of patients with COVID-19, compared to no cases in ill patients with non-COVID-19 [58, 131].

\section{Gastrointestinal Symptoms in Children}

In a recent meta-analysis, data were selected from 32 articles with a total sample size of 759 children [132]. Among the most common clinical manifestations was diarrhoea $(19 \%$, 95\% CI 9-28\%). Another systematic review reported data from 45 paediatric studies on SARS-CoV-2 infection. Paediatric infections were found to be $2 \%$ of 44,672 cases in a Chinese paper, $1.2 \%$ of 22,512 cases in an Italian study, $5 \%$ of 4226 cases in the United States and less than $1 \%$ of cases in the United Kingdom. Infections in paediatric patients are therefore a minority; this could be due to active resistance of children to the virus, or an increased frequency of unrecognized asymptomatic cases. The clinical course in the paediatric patient appears to be very mild compared to adults [133]. However, young patients (up to 5 years) have a higher viral RNA load in their nasopharynx than older ones and adults [134]. The most common symptoms in children are fever and cough, but diarrhoea and vomiting have also been reported. Table 2 and Table S2, respectively, show all studies with more than 100 or less than 100 children found by our search [135-211]. In children, GIS are less common than in H1N1 influenza, which, according to the data, in 2009 caused diarrhoea in more than $20 \%$ of children [212]. An essential aspect to consider is that, although children show mild or no symptoms, stool samples and rectal swabs may test positive for viral RNA for several days after infection. In addition, paediatric patients seem to eliminate the virus through faeces for a longer time than adults [213, 214]. Several authors have proposed that the paediatric patient, due to the scarcity of symptoms and the prolonged elimination of the virus with faeces, could be an essential vehicle for transmission. However, the role of children in the spread of the virus has not yet been fully clarified.

\section{Liver Involvement}

Patients with COVID-19 may experience liver injury with elevated enzymes in blood tests. ACE-2 is expressed abundantly in hepatocytes and, in particular, on biliary epithelial cells, and this justifies the frequent liver involvement during SARS-COV2 infection. The incidence of liver involvement ranges from $15 \%$ to $50 \%$ of patients presenting with increased levels of transaminase with a relatively mild elevation in serum bilirubin $[12,14,15,77,78]$, while, in patients with severe disease, the proportion of liver injury was also higher $[12,16,79,213]$. A recent meta-analysis calculated that up to $25 \%$ of patients would develop liver involvement

Table 2 Studies with more than 100 cases reporting gastrointestinal in COVID-19 patients. Paediatric population

\begin{tabular}{|c|c|c|c|c|c|c|c|}
\hline \multirow[t]{2}{*}{ Author } & \multirow[t]{2}{*}{ Patients $(n)$} & \multirow[t]{2}{*}{ Age (years) } & \multirow[t]{2}{*}{ Disease severity } & \multicolumn{4}{|c|}{ Gastrointestinal symptoms (\%) } \\
\hline & & & & Anorexia & Diarrhea & Nausea vomiting & Abdominal Pain \\
\hline Giacomet et al. [135] & 127 & $4.8(0.3-8.5)$ & Asymptomatic to critical & - & 22 & $-/ 9.4$ & 6.3 \\
\hline Garazzino et al. [136] & 168 & $5,2.3(0.3-9.6)$ & - & - & 13.1 & $-/ 5.4$ & - \\
\hline Du et al. [137] & 182 & $6(0-15.0)$ & Asymptomatic to critical & - & 4.9 & $-/ 3.8$ & 3.8 \\
\hline Gaborieau et al. [138] & 157 & $0.5(0.1-10)$ & Mild to severe & 10.2 & 15.3 & $-/ 7.6$ & - \\
\hline Guo et al. [139] & 341 & $7(0-14)$ & Asymptomatic to critical & - & 4.4 & 2.9 & - \\
\hline Rabha AC et al. [140] & 115 & $0.6-3$ & Asymptomatic to critical & 21.7 & 13 & 17,4 & 8.7 \\
\hline Bayesheva et al. [141] & 558 & $<19$ & Asymptomatic to critical & - & 2 & - & - \\
\hline Parri et al. [142] & 100 & $3.3(0-17.5)$ & Asymptomatic to severe & 23 & 9 & 10 & 4 \\
\hline $\begin{array}{l}\text { CDC COVID-19 } \\
\text { Response Team [143] }\end{array}$ & 291 & $11(0-17)$ & Asymptomatic to severe & - & 37 & 31 & 17 \\
\hline DeBiasi et al. [144] & 177 & $9.6(0.1-34.2)$ & Asymptomatic to severe & - & 15 & - & - \\
\hline Lu et al. [145] & 171 & $6.7(0-15)$ & Mild to severe & - & 8.8 & 6.4 & - \\
\hline Armann et al. [146] & 128 & $<18$ & Mild to severe & 17 & 17 & 17 & 17 \\
\hline Wu et al. [147] & 148 & $84(18-123)$ & Mild to moderate & - & 21.6 & 21.6 & - \\
\hline Zhen-Dong et al. [148] & 406 & 7 & Asymptomatic to death & - & 5.4 & 5.4 & - \\
\hline Feldstein et al. [149] & 186 & $9.1(4.1-11.7)$ & Severe to death & - & 92 & - & - \\
\hline Godfred-Cato et al. [150] & 570 & $8(4-12)$ & Mild to critical & - & 53.2 & 61.8 & 61.9 \\
\hline Guo et al. [151] & 136 & $7(0-14)$ & Asymptomatic to severe & - & 4.4 & 2.9 & - \\
\hline
\end{tabular}

Age expressed as mean \pm standard deviation or median (range) or range 
(95\% CI 0.16-0.33, $P<0.0001$ ) [215]. There are several possible mechanisms of liver damage: (1) immune-mediated hepatitis, (2) direct viral cytopathic effect, (3) drug-induced liver injury secondary to medications used for the treatment of COVID-19 disease (lopinavir, ritonavir, remdesivir, chloroquine, tocilizumab, umifenovir), (4) hypoxia secondary to lung disease enhancing hepatic damage, (5) infectioninduced systemic inflammation, (6) hepatic congestion secondary to positive pressure ventilation, and (7) reactivation of pre-existing liver disease [214].

A recent large retrospective cohort study, including 2073 Chinese patients with COVID-19, found that increased transaminases and direct bilirubin levels were independent predictors of mortality related to COVID-19 [215]. As far as acute-on-chronic liver (ACL) failure, among 192 hospitalised patients with chronic liver disease (CLD), 38\% of the 84 cirrhotics developed ACL disease. However, mortality was not different when comparing CLD patients with or without cirrhosis. Moreover, mortality was similar between the CLD cohort and matched control without CLD [216].

\section{Pancreatic Involvement}

Theoretically, pancreatic involvement is based on the evidence that ACE-2 is usually expressed in the pancreas (exocrine glands and islets) of healthy people, indicating that SARS-CoV-2 might also cause pancreatic injury and potentially contribute to islet damage [217]. Wang et al., in a retrospective study of 52 patients with COVID-19, described such pancreatic involvement: $17 \%$ of patients showed an abnormality in amylase $[115 \pm 25 \mathrm{U} / \mathrm{L}$ (normal value $<90$ ) or lipase $[71 \pm 34 \mathrm{U} / \mathrm{L}$ (normal value $<70)]$ and six had elevated levels of blood glucose suggestive of pancreatic islet damage. Patients with pancreatic injury had a higher incidence of anorexia and diarrhoea, more severe illness on admission, lower levels of CD3 + T-cell and CD4 + T-cell and higher levels of AST, GGT, creatinine, LDH and ESR. It is possible that some critically ill patients already had pancreatic damage on admission, and that this had been caused by drugs (NSAIDs and glucocorticoids) [81]. DeMadaria E. et al. replied that the definition of pancreatic injury, as referred by Wang et al., lacks specificity and does not meet Atlanta's criteria. A mild increase in blood levels of pancreatic enzymes within the threefold upper normal limits threshold can be explained by many factors other than direct viral damage, and the authors did not provide data on imaging techniques, which are crucial for diagnosing pancreatitis [218]. In another recent systematic review, cases of acute pancreatic disease associated with SARS-CoV-2 were searched to assess whether there was an association between the two. Six case reports and two retrospective cohort studies were selected but, unfortunately, the etiological factors and diagnostic criteria applied are not always well described [219].

In conclusion, the risk of pancreatic involvement related to Covid-19 and the subsequent risk of acute pancreatitis exist. However, the clinical relevance of mildly elevated pancreatic enzymes in COVID-19 is unknown.

\section{Covid-19 and Chronic GI and Liver Disorders}

\section{Inflammatory Bowel Disease (IBD)}

GIS appear to be secondary to intestinal inflammation, as evidenced by a recent study showing a strong correlation between the presence of diarrhoea and the elevation of faecal calprotectin and serum IL-6 [80]. Moreover, the examination of serum inflammatory markers showed elevated levels of procalcitonin, $\mathrm{C}$ reactive protein, $\mathrm{D}$-dimer, ferritin tumour necrosis factor, interleukin (IL)-2R, IL-6, IL-8 and IL-10 [220]. These findings raise the question of whether the presence of the virus could be responsible for relapse in patients with inflammatory bowel disease (IBD), especially if requiring immunosuppressive drugs. ACE-2 receptor is highly expressed in inflamed IBD mucosal samples compared to controls. In addition, cytokines expressed in IBD, such as interferon-gamma, can potentially induce ACE-2 expression, consistent with the idea that mucosal inflammation can increase ACE- 2 expression. These results indicate that patients with IBD might be especially vulnerable to COVID19; nevertheless, there is no evidence that this is the case. In a recent systematic review and meta-analysis, data from 11 studies were reported to evaluate the various clinical manifestations of SARS-CoV-2 in patients with IBD [221].

Diarrhoea was the most common GI manifestation in IBD patients $(27.26 \%$; 95\% CI 19.51-36.69; I2 = 87\%) per 100 persons. The pooled prevalence was $13.08 \%$ for abdominal pain $(95 \%$ CI $9.24-18.19$; I2 = 69\%), $10.08 \%$ for nausea $(95 \%$ CI $5.84-16.85 ; \mathrm{I} 2=80 \%)$ and $8.80 \%$ for vomiting $(95 \%$ CI $4.43-16.70 ; \mathrm{I} 2=85 \%)$ per 100 persons. A noteworthy finding was the preponderance of abdominal pain in IBD patients, which is not common in the COVID-19-infected general population, as seen in other investigations. The current literature indicates that there is no evidence of increased risk or worsened outcomes in COVID-19 patients with IBD [222].

Covid-19 seems to be more severe in old patients and in those with comorbidities (e.g. coronary heart disease, obesity, diabetes mellitus, malnutrition, cardiovascular disease, obstructive pulmonary disease and hypertension), severe IBD and/or needing surgery [223]. Considering the risk of flare-ups leading to a need for steroids or other potential immunosuppression or hospitalisation, the British Society of Gastroenterology, in a document addressing the 
needs of IBD patients, does not recommend interrupting or decreasing medications without first addressing it with the IBD team. Moreover, physicians must consider that immunosuppressive drug effects can persist for several weeks or months following cessation of treatment and that the evidence available indicates that patients with IBD do not have an elevated risk of developing COVID-19. Patients that receive immune suppressants should be closely monitored for symptoms and/or signs that indicate COVID-19. In addition, those patients over 60 years of age and/or with comorbidities who have a higher risk of SARS-CoV-2 induced pneumonia should remain at home and avoid public gatherings [224]. An international adult and paediatric registry (Surveillance Epidemiology of Coronavirus Under Research Exclusion-SECURE-IBD) is available to collect all the cases of COVID-19 in IBD patients at www.covidibd.org. This registry will help to define the impact of COVID-19 in these patients and how factors such as age, severity, comorbidities and IBD treatments impact COVID-19 outcomes. Data on the effects of IBD medications on COVID-19 outcomes extrapolated from the registry have been recently published. The study, which includes 1439 cases from 47 countries, demonstrated that combination therapy and thiopurines may determine a worst COVID-19 outcome, while no differences were observed comparing different classes of biological drugs [225].

\section{Celiac Disease}

To date, no research has shown that patients with celiac disease (CD) are at an elevated risk of severe COVID-19 as compared to patients without $\mathrm{CD}$.

As for IBDs and also for CD patients, an international registry is currently collecting data of patients to monitor and report the outcomes of COVID-19 occurring in patients with celiac disease (SECURE-Celiac). The database encourages clinicians worldwide to report all cases of COVID-19 in celiac patients, regardless of severity (including asymptomatic patients identified through health screening). The database is accessible at https://covidceliac.org/.

The CD Foundation Medical Advisory Board reports that patients with $\mathrm{CD}$ are not usually considered immunocompromised. A small number of $\mathrm{CD}$ patients with extreme malnutrition and weight loss, type 2 refractory $\mathrm{CD}$, immunosuppressive medications or other serious illnesses may be at an elevated risk of severe COVID-19 and should consult with their physicians. CD is a chronic medical condition with a slightly elevated risk of infection, community-acquired pneumonia and worse outcomes with influenza [226] and therefore might benefit from an implementation of a vaccination programme for Streptococcus pneumonia and influenza. High-coverage vaccination programmes may help reduce the stress on the national healthcare system: e.g. avoiding being misled by diseases that can cause influenza-like symptoms in particular during the cold season during a pandemic, and also lower coinfections that could increase potential COVID19 mortality. It is fair to hypothesise that those with $\mathrm{CD}$, particularly the elderly, maybe at a slightly increased risk of worse infections with this new virus. Recently, Siniscalchi et al. surveyed 276 patients with CD using an ad hoc COVID-19 survey. He found that the lockdown had a small effect on patients' psychological health: CD patients did not think they were at excessive risk of being infected with the Sars-COV-2 virus nor worried about the shortage of gluten-free food. Elderly patients and patients with other comorbidities were the most worried, probably because they knew they were at greater risk of mortality [227]. In another recent survey of 1983 responses, improved adherence to the gluten-free diet was reported for $29 \%$ of enrolled adults and children [228].

Based on a retrospective cohort study, another paper has been published on the management of $\mathrm{CD}$ in children with antitranglutaminase IgA between 5 and 10 times the upper limit of normal and positive endomysial antibodies during the COVID-19 outbreak.

The authors conclude for the possibility of temporarily reducing the antitranglutaminase IgA threshold for a biopsysparing approach, avoiding delayed diagnosis and complications. Certainly, a rigorous follow-up of illness course and serum auto-antibody levels is extremely crucial to confirm diagnoses over time [229].

\section{Chronic Liver Disease}

Since the pandemic began, several studies have been conducted to assess a link between underlying liver diseases and the course of SARS-CoV-2 infection. Patients that might be at increased risk of a severe course of COVID-19 are those with chronic hepatitis $\mathrm{B}$ and $\mathrm{C}$ or cirrhosis, alcoholassociated liver disease, non-alcoholic fatty liver disease or steatohepatitis that may suffer from metabolic comorbidities such as diabetes, hypertension and obesity [230, 231].

According to the World Gastroenterology Organization, patients with chronic liver disease without cirrhosis and/ or after liver transplantation are not at an increased risk of severe COVID-19 disease. Some general approaches are strongly recommended: (1) reduce direct exposure and maintain social distance; (2) maintain care according to guidelines; (3) routine testing of liver biochemistry is not recommended for outpatients; (4) exclude viral hepatitis in patients with elevated transaminase; (5) maintain antiviral medications for B or C hepatitis; (6) delay nonurgent procedures of surveillance such as liver ultrasound and screening; (7) maintain immunosuppressive therapy if not differently prescribed; (8) use telemedicine whenever possible; (9) implement vaccination for Streptococcus 
pneumonia and influenza; (10) limit contact with medical personnel to a minimum; and (11) promote collaboration with local health care providers and primary care facilities. Additional recommendations for patients with decompensated liver disease include that listing for transplantation should be restricted to patients with poor short-term prognosis and that in-hospital liver transplant evaluation programmes should be maintained aiming to shorten hospital stays. A patient with chronic liver disease who results positive to COVID-19 should be admitted for in-patient care in the presence of additional risk factors for a more severe COVID-19 course like hypertension, diabetes, obesity, cirrhosis or a post-transplant status. A patient with chronic liver disease, negative to COVID-19 who needs in-patient care should be admitted to COVID-19-clean hospitals, preferably in private rooms, and specialised centres should provide easily accessible hepatology consultations [232].

At the beginning of the Sars-Cov-2 pandemic, there was much concern about liver-transplanted patients since they were theoretically at higher risk of COVID-19 because of chronic immunosuppression. However, a prior experience of Italian patients found that none of the transplanted patients on highly intensive immunosuppression experienced a more severe disease course [233]. A more recent prospective Spanish nationwide study reported that, although liver transplant patients are chronically immunosuppressed and have an increased risk of acquiring COVID-19, their mortality rate is lower than the matched general population [234].

\section{GI Procedures During Covid-19 Pandemic}

\section{Endoscopic Procedures}

At the beginning of the pandemic, multi-society guidelines recommended the postponement of non-emergency endoscopic procedures in adults and children [235-237]. Nowadays, the recommendations for diagnostic procedures are a dynamic process that needs to be updated regularly. It remains a good rule to screen with a COVID-19 questionnaire about the presence of symptoms, the history of potential exposure to infected individuals, travel to/from the containment zone and vaccination. Another suggestion is to use pre-endoscopy viral testing, although these are not routinely available everywhere. In the latter case, viral testing should be reserved for those patients at high risk of having COVID-19 infection after the questionnaire. Digestive endoscopy in COVID patients with GI symptoms showed variable results: oedema of the lamina propria (reported in two of three studies) and the presence of the virus in various levels of the GI tract [72, 78, 238].

\section{Liver Biopsy}

Recommendations can be examined based on individual risk-benefit considerations. Routine liver biopsy is not recommended in COVID-19 patients with liver test abnormalities. Liver biopsy should be deferred whenever possible in the event of non-alcoholic fatty liver disease or chronic viral hepatitis grading/staging and when the clinical indication is not urgent such as in the case of mildly elevated transaminases of unknown aetiology. Even in cases of autoimmune liver disease the biopsy should be postponed and an empiric therapy recommended. Liver biopsy should not be delayed in the event of liver masses suspected of malignancy [232].

\section{Faecal Transplantation}

An international panel of experts in faecal microbiota transplantation and stool banking recommends updating the screening of stool donors, as the risk of faecal transplantation of SARS-CoV-2 may be high [239]. Faecal microbiota transplantation is not regulated in the same way worldwide: some countries control it as a drug (USA, UK, France) and some as a tissue (Italy). In contrast, others do not provide for precise regulation (Australia) [240], and this complicates the situation, possibly leading to the spread of the infection. A more troubling concern is the unauthorised practice of homemade faecal microbiota transplantation, which is common among patients who would like to seek this treatment for reasons outside treatment protocols or clinical trials. The authors propose the screening of donors for the existence of risk factors for COVID-19: symptoms, travel history, and interaction within the previous 30 days with individuals with confirmed or suspected dangerous infections. The RT-PCR assay should be considered in all donors in endemic countries. In addition, donor stools should be processed and quarantined 30 days before use and released if symptoms do not appear in the donor. According to other authors, to ensure secure and efficient FMT to critically ill patients with persistent and refractory $C$. difficile infection, enhanced donor screening and validated stool tests for SARS-CoV-2 are needed [241]. However, faecal microbiota transplantation for these patients should be postponed until the pandemic is better under controlled conditions [242].

\section{Covid-19 and Special Conditions}

\section{SARS-CoV-2 and Faecal-Oral Transmission}

SARS-CoV-2 belongs to viruses with intermediate respiratory and faecal-oral transmission capacity. The finding of viral RNA in faeces and anal and rectal swabs, reported in several studies, suggests the possibility of faecal-oral 
transmission. In the 2002-2003 SARS outbreak, SARS-CoV RNA was found in stools only after the fifth day of disease, and the proportion of stool-positive specimens steadily increased, peaking on day 11, with viral RNA still present for up to a month. It would also appear that the survival of the virus in the faeces is longer than in the respiratory tract. If this is also confirmed for SARS-CoV-2, doubts about the appropriateness of the current discharge criteria, based on the negative detection of the virus in two respiratory samples obtained $24 \mathrm{~h}$ apart, might arise. Table 3 reports the studies evaluating the presence of the SARS-CoV-2 in faecal specimens $[60,72-75,78,80,91,94,96,114,119,154$, $155,158,171,207,210,243-281]$. No relationship has been reported between the persistence of the virus in the faeces, the severity of disease and the presence of GIS. In a recent meta-analysis, it was shown that positive faecal samples from $64 \%$ of patients remained positive for SARS-CoV-2 for an average of 12.5 days, up to a maximum of 33 days, after respiratory samples became negative for SARS-CoV-2, making faecal-oral transmission plausible [282].

This finding is different from what has been reported with MERS, where the derangement of the gut epithelium was related to the subsequent development of pneumonia and severe disease [91]. In the United States, SARS-CoV-2 was first identified in stool samples. The possible faecal-oral transmission supports the necessity of strict measures while handling the stools of coronavirus-infected patients as well as adequate disinfection of hospital wastewater.

\section{Covid-19 and Gut Microbiota}

The lung and the gut are linked by a continuous two-way dialogue, each influencing the conditions of the other. Although the connection between these two systems is not yet fully understood, we know that the gut plays a central role, both because a break in the mucosal barrier may lead to the passage of endotoxins, bacterial metabolites and hormones in the body, and because gut microbiota are in constant communication with the immune system. During acute pulmonary disease, bacteria of intestinal origin can be found in the lungs secondary to bacterial translocation. Recent research has shown that the mucosal surfaces of the gastrointestinal and respiratory tract comprise distinct microbial species, both with overt and indirect effects on host defences against viral lung infections. Moreover, antiviral immune responses caused by acute respiratory infections, such as influenza, are associated with changes in respiratory and gastrointestinal microbiota (dysbiosis), which may affect the resulting function of the immune system [283]. As mentioned above, ACE-2 is crucial for the expression in the small intestine of some amino acid transporters, and, through this, ACE-2 can regulate intestinal microbiome composition [11]. In addition, gut microbiota could influence the action or change the expression of ACE-2.

In a recent study, Gu et al. reported a significant decrease in microbial diversity in intestinal microbiota specimens collected from COVID-19 patients in comparison with those collected from healthy controls [284]. Furthermore, they observed typical signs of dysbiosis: an increase of opportunistic pathogens and a decrease in the abundance of beneficial microbes, including microbial bacteria belonging to the Ruminococcaceae and Lachnospiraceae families. Zuo et al. showed significant alterations in the gut microbiome in COVID-19 patients [285], and demonstrated an inverse correlation between the abundance of Faecalibacterium prausnitzii, considered a beneficial intestinal species, and SARS-COV-2 severity. Sufficient data are not yet available on the influence of the microbiota on the clinical course of COVID-19 and the onset of GI symptoms nor on the effect of COVID-19 on the integrity of the intestinal barrier or the onset of dysbiosis.

\section{Conclusions}

We have provided an update on the prevalence of gastrointestinal symptoms and liver injury in COVID-19 patients, showing that digestive symptoms and liver injury are not uncommon in COVID-19 patients, in particular in severe ones. Children with COVID-19 seem to have a milder course of GI and liver involvement as compared to adults. Patients with GI tract involvement as initial symptoms may have a delayed diagnosis of COVID-19. Moreover, those with digestive involvement tend to progress towards severe or critical illness and an unfortunate course of the disease. More attention should be paid to early identification of these patients. SARS-CoV-2 does not increase the risk of aggravation of disease among patients with pre-existing GI or liver-related comorbidities. However, these patients might benefit from an implementation of vaccination programmes, reducing possible direct exposure to the virus and maintaining social distance and care according to guidelines possibly through telemedicine without the need for reducing/stopping immunosuppressive treatment.

Nonetheless, limitations should be reported. First of all, the central core of researches has been written in other languages, particularly in Chinese. Then, GISs seem to be underreported because some symptoms were not taken into account or they were not considered as relevant or even more not categorised. In summary, the fast-evolving literature on this new pathological entity makes the gathering of new information highly relevant, since a better understanding and up-to-date knowledge of all available information might be useful, not only for scientific purposes but also for 
Table 3 Presence of SARSCoV-2 viral RNA in specimens from GI tract

\begin{tabular}{|c|c|c|c|}
\hline Study & Patients $(n)$ & Sample & Positivity rate (\%) \\
\hline Xiao et al. [72] & 73 & Stool & 53.4 \\
\hline Lo et al. [73] & 10 & Stool & 100 \\
\hline To et al. [74] & 15 & Rectal swabs & 27 \\
\hline Wu et al. [75] & 74 & Stool & 55 \\
\hline Lin et al. [78] & 65 & Stool & 47.7 \\
\hline Effenberger et al. [80] & 40 & Stool & 30 \\
\hline Cheung et al. [94] & 59 & Stool & 15.3 \\
\hline Chen et al. [243] & 28 & Anal swabs & 39.28 \\
\hline Zhang et al. [244] & 14 & Stool & 37.5 \\
\hline Chen et al. [96] & 42 & Stool & 66.67 \\
\hline Zhang et al. [245] & 16 & Anal swabs & 62.5 \\
\hline Tan et al. [154] & 10 & Stool & 30 \\
\hline Zheng et al. [91] & 96 & Stool & 59 \\
\hline Xu et al. [155] & 10 & Rectal swabs & 80 \\
\hline Wu et al. [246] & 132 & Stool/Anal swabs & $9.83 / 10$ \\
\hline Wang et al. [247] & 153 & Stool & 29 \\
\hline Zhao et al. [119] & 401 & Rectal swabs & 20 \\
\hline Xiong et al. [158] & 105 & Stool & 37.1 \\
\hline Zuo et al. [114] & 15 & Stool & 46.7 \\
\hline Díaz et al. [60] & 12 & Stool & 50 \\
\hline Lei et al. [248] & 217 & Anal swabs & 21.2 \\
\hline Peng et al. [249] & 38 & Anal swabs & $\begin{array}{l}\text { Disease onset: } 14.9 \\
\text { Recovery: } 29.8\end{array}$ \\
\hline Liu et al. [250] & 47 & Anal swabs & $\begin{array}{l}\text { Morning: } 2.5 \\
\text { Afternoon: } 5\end{array}$ \\
\hline Huang et al. [251] & 19 & Anal swabs & 21.1 \\
\hline Li et al. [252] & 100 & Anal swabs & 20.2 \\
\hline Peng et al. [253] & 9 & Anal swabs & 22 \\
\hline Novazzi et al. [254] & 107 & Rectal swabs & 10.3 \\
\hline Zhang et al. [255] & 61 & Stool & 9.83 \\
\hline Wu et al. [256] & 91 & Stool & 86.8 \\
\hline De Ioris et al. [210] & 22 & Stool & 68 \\
\hline Chen et al. [257] & 97 & Faecal/perianal swabs & 53.61 \\
\hline He et al. [258] & 20 & Stool & 55 \\
\hline Lu et al. [259] & 73 & Stool & 54.8 \\
\hline Wang et al. [260] & 69 & Stool & 28.99 \\
\hline Shi et al. [261] & 99 & Stool & 21.2 \\
\hline Deng et al. [262] & 61 & Stool & 27.9 \\
\hline Lei et al. [263] & 7 & Stool & 57.1 \\
\hline Lu et al. [264] & 28 & Stool & 40.74 \\
\hline Shang et al. [265] & 564 & Stool & $\begin{array}{l}\text { Patients with diarrhoea: } 63.9 \\
\text { Respiratory only: } 14.3\end{array}$ \\
\hline Han et al. [266] & 12 & Stool & 92 \\
\hline Xu et al. [267] & 23 & Stool & 69.6 \\
\hline Han et al. [268] & 206 & Stool & $\begin{array}{l}\text { Digestive symptoms: } 73.3 \\
\text { Respiratory only: } 14.3\end{array}$ \\
\hline Lin et al. [269] & 217 & Anal swabs & 21.2 \\
\hline Wei et al. [270] & 84 & Stool & $\begin{array}{l}\text { With diarrhoea: } 69 \\
\text { Without diarrhoea: } 17\end{array}$ \\
\hline Ling et al. [271] & 66 & Stool & 16.7 \\
\hline Turriziani et al. [272] & 134 & Stool & 19.4 \\
\hline
\end{tabular}


Table 3 (continued)

\begin{tabular}{llll}
\hline Study & Patients $(n)$ & Sample & Positivity rate (\%) \\
\hline Jiehao et al. [273] & 6 & Stool & 83.3 \\
Yin et al. [274] & 33 & Stool & 24.2 \\
COVID-19 Investigation & 10 & Stool & 70 \\
$\quad$ Team [275] & & & \\
Hua et al. [207] & 35 & Stool & 91.4 \\
Sun et al. [276] & 49 & Stool & 44.12 \\
Kim et al. [277] & 74 & Stool & 10.1 \\
Young et al. [278] & 8 & Stool & 50 \\
Wu et al. [171] & 74 & Stool & 13.51 \\
Mesoraca et al. [279] & 15 & Stool & 33 \\
Du et al. [280] & 10 & Stool & 70 \\
Zhou et al. [281] & 42 & Anal swabs & 14.3
\end{tabular}

the practical implications so as to provide the best care for our patients.

Supplementary Information The online version contains supplementary material available at https://doi.org/10.1007/s10620-021-07158-0.

Author's contributions RF, MB and VF drafted the article and made critical revisions related to important intellectual content of the manuscript; GC, MAM, FC and VND made substantial contributions to the conception and design of the study, the acquisition of the data and its analysis and interpretation; RG and CD performed the literature search and data analysis. All the authors revised the manuscript and gave final approval of the version of the article to be published.

Funding Open access funding provided by Università degli Studi di Bari Aldo Moro within the CRUI-CARE Agreement. The present study did not receive any financial support.

\section{Declarations}

Conflict of interest The authors have no conflicts of interest relevant to this article to disclose.

Open Access This article is licensed under a Creative Commons Attribution-NonCommercial 4.0 International License, which permits any non-commercial use, sharing, adaptation, distribution and reproduction in any medium or format, as long as you give appropriate credit to the original author(s) and the source, provide a link to the Creative Commons licence, and indicate if changes were made. The images or other third party material in this article are included in the article's Creative Commons licence, unless indicated otherwise in a credit line to the material. If material is not included in the article's Creative Commons licence and your intended use is not permitted by statutory regulation or exceeds the permitted use, you will need to obtain permission directly from the copyright holder. To view a copy of this licence, visit http://creativecommons.org/licenses/by-nc/4.0/.

\section{References}

1. World Health Organization. Covid-19 2020. https://www.who. $\mathrm{int/docs/default-source/coronaviruse/situation-reports/20200}$ 515-covid-19-sitrep-134.pdf?sfvrsn=8dd60956_2. Accessed 03.06.20.

2. Badawi A, Ryoo SG. Prevalence of comorbidities in the Middle East respiratory syndrome coronavirus (MERS-CoV): a systematic review and meta-analysis. Int $J$ Infect Dis 2016;49:129-133. https://doi.org/10.1016/j.ijid.2016.06.015.

3. Guo YR, Cao QD, Hong ZS, Tan YY, Chen SD, Jin HJ et al. The origin, transmission and clinical therapies on coronavirus disease 2019 (COVID-19) outbreak-an update on the status. Mil Med Res 2020;7:11. https://doi.org/10.1186/ s40779-020-00240-0.

4. Lu R, Zhao X, Li J, Niu P, Yang B, Wu H et al. Genomic characterisation and epidemiology of 2019 novel coronavirus: implications for virus origins and receptor binding. Lancet 2020;395:565-574. https://doi.org/10.1016/S0140-6736(20) 30251-8.

5. Wrapp D, Wang N, Corbett KS, Goldsmith JA, Hsieh CL, Abiona O et al. Cryo-EM structure of the 2019-nCoV spike in the prefusion conformation. Science 2020;367:1260-2126. https://doi.org/ 10.1126/science.abb2507.

6. Yan R, Zhang Y, Li Y, Xia L, Guo Y, Zhou Q. Structural basis for the recognition of SARS-CoV-2 by full-length human ACE2. Science 2020;367:30-31. https://doi.org/10.1126/science.abb27 62.

7. Hamming I, Timens W, Bulthuis ML, Lely AT, Navis G, van Goor H. Tissue distribution of ACE2 protein, the functional receptor for SARS coronavirus. A first step in understanding SARS pathogenesis. J Pathol 2004;203:631-637. https://doi. org/10.1002/path.1570.

8. Du M, Cai G, Chen F, Christiani DC, Zhang Z, Wang M. Multiomics evaluation of gastrointestinal and other clinical characteristics of SARS-CoV-2 and COVID-19. Gastroenterology 2020;158:2298-2301.e7. https://doi.org/10.1053/j.gastro.2020. 03.045 .

9. Xu H, Zhong L, Deng J, Peng J, Dan H, Zeng X et al. High expression of ACE2 receptor of 2019-nCoV on the epithelial cells of oral mucosa. Int J Oral Sci 2020;12:8. https://doi.org/ 10.1038/s41368-020-0074-x.

10. Zhang H, Kang Z, Haiyi G, Xu D, Wang J, Li Z, Cui X, Xiao J, Meng T, Zhou W, Liu J, Xu H. The digestive system is a potential route of 2019-nCov infection: a bioinformatics analysis based on single-cell transcriptomes. bioRxiv Preprint. Available at: https:// doi.org/10.1101/2020.01.30.927806v1. Cited June 2020.

11. Perlot T, Penninger JM. ACE2-from the renin-angiotensin system to gut microbiota and malnutrition. Microbes Infect 2013;15:866-873. https://doi.org/10.1016/j.micinf.2013.08.003. 
12. Wang D, Hu B, Hu C, Zhu F, Liu X, Zhang J et al. Clinical characteristics of 138 hospitalized patients with 2019 novel coronavirus-infected pneumonia in Wuhan, China. JAMA 2020;323:1061-1069.

13. Han R, Huang L, Jiang H, Dong J, Peng H, Zhang D. Early clinical and CT manifestations of coronavirus disease 2019 (COVID19) pneumonia. Am J Roentgenol. 2020. https://doi.org/10.2214/ AJR.20.22961.

14. Pan L, Mu M, Ren HG, Yang PC, Sun Y, Wang RS et al. Clinical characteristics of COVID-19 patients with digestive symptoms in Hubei, China: a descriptive, cross sectional, multicenter study. Am J Gastroenterol 2020;115:766-773. https://doi.org/10.14309/ ajg.0000000000000620.

15. Cholankeril G, Podboy A, Aivaliotis VI, Tarlow B, Pham EA, Spencer $\mathrm{S}$ et al. High prevalence of concurrent gastrointestinal manifestations in patients with SARS-CoV-2: early experience from California. Gastroenterology 2020;S0016-5085:3047130476. https://doi.org/10.1053/j.gastro.2020.04.008.

16. Guan WJ, Ni ZY, Hu Y, Liang WH, Ou CQ, He JX et al. Clinical Characteristics of Coronavirus Disease 2019 in China. $N$ Engl $J$ Med 2020;382:1708-1720. https://doi.org/10.1056/NEJMoa2002 032.

17. Zhang Y, Zheng L, Liu L, Zhao M, Xiao J, Zhao Q. Liver impairment in COVID-19 patients: a retrospective analysis of 115 cases from a single centre in Wuhan city, China. Liver Int. 2020. https://doi.org/10.1111/liv.14455.

18. Wang X, Fang J, Zhu Y, Chen L, Ding F, Zhou R et al. Clinical characteristics of non-critically ill patients with novel coronavirus infection (COVID-19) in a Fangcang Hospital. Clin Microbiol Infect. 2020. https://doi.org/10.1016/j.cmi.2020.03.032.

19. Chen J, Qi T, Liu L, Ling Y, Qian Z, Li T et al. Clinical progression of patients with COVID-19 in Shanghai, China. J Infect 2020;80:e1-e6. https://doi.org/10.1016/j.jinf.2020.03.004.

20. Liu K, Fang YY, Deng Y, Liu W, Wang MF, Ma JP et al. Clinical characteristics of novel coronavirus cases in tertiary hospitals in Hubei Province. Chin Med J 2020;133:1025-1031. https://doi. org/10.1097/CM9.0000000000000744.

21. Zhou F, Yu T, Du R et al. Clinical course and risk factors for mortality of adult inpatients with COVID-19 in Wuhan, China: a retrospective cohort study. Lancet 2020;395:1054-1062. https:// doi.org/10.1016/S0140-6736(20)30566-3.

22. Zhou Z, Zhao N, Shu Y et al. Effect of gastrointestinal symptoms on patients infected with COVID-19. Gastroenterology 2020;158:2294-2297. https://doi.org/10.1053/j.gastro.2020.03. 020.

23. Guo W, Li M, Dong Y et al. Diabetes is a risk factor for the progression and prognosis of COVID-19. Diabetes Metab Res Rev. 2020. https://doi.org/10.1002/dmrr.3319.

24. Shi S, Qin M, Shen B et al. Association of cardiac injury with mortality in hospitalized patients with COVID-19 in Wuhan, China. JAMA Cardiol. 2020. https://doi.org/10.1001/jamacardio. 2020.0950.

25. Redd WD, Zhou JC, Hathorn KE, McCarty TR, Bazarbashi AN, Thompson CC et al. Prevalence and characteristics of gastrointestinal symptoms in patients with SARS-CoV-2 infection in the United States: a multicenter cohort study. Gastroenterology 2020;S0016-5085:30564-30573. https://doi.org/10.1053/j.gastro.2020.04.045.

26. Jin X, Lian JS, Hu JH, Gao J, Zheng L, Zhang YM et al. Epidemiological, clinical and virological characteristics of 74 cases of coronavirus-infected disease 2019 (COVID-19) with gastrointestinal symptoms. Gut 2020;69:1002-1009. https://doi.org/10. 1136/gutjnl-2020-320926.

27. Nobel YR, Phipps M, Zucker J, Lebwohl B et al. Gastrointestinal symptoms and Coronavirus Disease 2019: a case-control study from the United States. Gastroenterology 2020;159:373-375.e2. https://doi.org/10.1053/j.gastro.2020.04.017.

28. Klopfenstein T, Kadiane-Oussou NJ, Royer PY, Toko L et al. Diarrhea: an underestimated symptom in Coronavirus disease 2019. Clin Res Hepatol Gastroenterol. 2020;44:282-283. https:// doi.org/10.1016/j.clinre.2020.04.002.

29. Cholankeril G, Podboy A, Aivaliotis VI, Pham E et al. Association of digestive symptoms and hospitalization in patients with SARS-CoV-2 infection. Am J Gastroenterol 2020;115:11291132. https://doi.org/10.14309/ajg.0000000000000712.

30. Moura DTH, Proença IM, McCarty TR, Sagae VMT et al. Gastrointestinal manifestations and associated health outcomes of COVID19: a Brazilian experience from the largest South American Public Hospital. Clinics (Sao Paulo) 2020;75:e2271. https:// doi.org/10.6061/clinics/2020/e2271.

31. Rao X, Wu C, Wang S, Tong S et al. The importance of overweight in COVID-19: a retrospective analysis in a single center of Wuhan, China. Medicine (Baltimore) 2020;99:e22766. https:// doi.org/10.1097/MD.0000000000022766.

32. Du L, Cao X, Chen J, Wei X et al. Fecal occult blood and urinary cytology tests for rapid screening of inflammatory infection in the gastrointestinal and urological systems in patients with Coronavirus disease 2019. J Clin Lab Anal 2021;35:e23626. https:// doi.org/10.1002/jcla.23626.

33. Jalali SF, Ghassemzadeh M, Mouodi S, Javanian M et al. Epidemiologic comparison of the first and second waves of coronavirus disease in Babol, North of Iran. Caspian J Intern Med 2020;11:544-550. https://doi.org/10.22088/cjim.11.0.544.

34. Khalil MM, Gain G, Mahbub-Uz-Zaman K, Karim ME et al. Gastrointestinal manifestations among COVID-19 Patients in Bangladesh: a cross sectional study. Mymensingh Med J. 2020;29:956-963.

35. Elmunzer BJ, Spitzer RL, Foster LD, Merchant AA et al. North American alliance for the study of digestive manifestations of COVID-19. Digestive manifestations in patients hospitalized with Coronavirus disease 2019. Clin Gastroenterol Hepatol. 2020. https://doi.org/10.1016/j.cgh.2020.09.041.

36. Laszkowska M, Faye AS, Judith Truong H, Silver ER et al. Disease course and outcomes of COVID-19 among hospitalized patients with gastrointestinal manifestations. Clin Gastroenterol Hepatol. 2020. https://doi.org/10.1016/j.cgh.2020.09.037.

37. Kang MK, Kim KO, Kim MC, Cho JH et al. Clinical characteristics of coronavirus disease 2019 patients with diarrhea in Daegu. Korean J Intern Med. 2020;35:1261-1269. https://doi. org/10.3904/kjim.2020.196.

38. Sulaiman T, Algharawi AA, Idrees M, Alzaidy RH et al. The prevalence of gastrointestinal symptoms among patients with COVID-19 and the effect on the severity of the disease. JGH Open. 2020;4:1162-1166. https://doi.org/10.1002/jgh3.12415.

39. Livanos AE, Jha D, Cossarini F, Gonzalez-Reiche AS et al. Gastrointestinal involvement attenuates COVID-19 severity and mortality. medRxiv. 2020. https://doi.org/10.1101/2020.09.07.20187 666.

40. Renelus BD, Khoury N, Chandrasekaran K, Bekele E et al. Hospitalized coronavirus disease-2019 (COVID-19) patients with gastrointestinal symptoms have improved survival to discharge. Dig Liver Dis 2020;52:1403-1406. https://doi.org/10.1016/j.dld. 2020.08.043.

41. Bannaga AS, Tabuso M, Farrugia A, Chandrapalan S et al. $\mathrm{C}$-reactive protein and albumin association with mortality of hospitalised SARS-CoV-2 patients: a tertiary hospital experience. Clin Med (Lond) 2020;20:463-467. https://doi.org/10. 7861/clinmed.2020-0424.

42. Lei $\mathrm{P}$, Zhang $\mathrm{L}$, Han $\mathrm{P}$, Zheng $\mathrm{C}$ et al. Liver injury in patients with COVID-19: clinical profiles, CT findings, the correlation 
of the severity with liver injury. Hepatol Int 2020;14:733-742. https://doi.org/10.1007/s12072-020-10087-1.

43. Ianiro G, Porcari S, Settanni CR, Bibbò S, et al. Gemelli against COVID-19 Working Group. Letter: prevalence and patterns of gastrointestinal symptoms in a large Western cohort of patients with COVID-19. Aliment Pharmacol Ther. 2020 Nov;52(9):1535. https://doi.org/10.1111/apt.15946

44. Hajifathalian K, Krisko T, Mehta A, Kumar S, et al. WCM-GI research group*. Gastrointestinal and hepatic manifestations of 2019 novel Coronavirus disease in a large cohort of infected patients from New York: clinical implications. Gastroenterology. 2020;159:1137-1140.e2. https://doi.org/10.1053/j.gastro. 2020.05.010

45. Zhang H, Liao YS, Gong J, Liu J et al. Clinical characteristics of coronavirus disease (COVID-19) patients with gastrointestinal symptoms: a report of 164 cases. Dig Liver Dis. 2020;52:10761079. https://doi.org/10.1016/j.dld.2020.04.034.

46. Aghemo A, Piovani D, Parigi TL, Brunetta E et al. Humanitas COVID-19 task force. COVID-19 digestive system involvement and clinical outcomes in a large academic hospital in Milan, Italy. Clin Gastroenterol Hepatol 2020;18:2366-2368.e3. https://doi. org/10.1016/j.cgh.2020.05.011.

47. Chen A, Agarwal A, Ravindran N, To C et al. Are gastrointestinal symptoms specific for Coronavirus 2019 infection? A prospective case-control study from the United States. Gastroenterology 2020;159:1161-1163.e2. https://doi.org/10.1053/j.gastro.2020. 05.036.

48. Zhao F, Yang Y, Wang Z, Li L et al. The time sequences of respiratory and rectal viral shedding in patients with Coronavirus disease 2019. Gastroenterology 2020;159:1158-1160.e2. https:// doi.org/10.1053/j.gastro.2020.05.035.

49. Ferm S, Fisher C, Pakala T, Tong M et al. Analysis of gastrointestinal and hepatic manifestations of SARS-CoV-2 infection in 892 patients in Queens, NY. Clin Gastroenterol Hepatol 2020;18:2378-2379.e1. https://doi.org/10.1016/j.cgh.2020.05. 049.

50. Sierpiński R, Pinkas J, Jankowski M, Zgliczyński WS et al. Sex differences in the frequency of gastrointestinal symptoms and olfactory or taste disorders in 1942 nonhospitalized patients with coronavirus disease 2019 (COVID-19). Pol Arch Intern Med. 2020;130:501-505. https://doi.org/10.20452/pamw.15414.

51. Cao C, Chen M, He L, Xie J, Chen X. Clinical features and outcomes of COVID-19 patients with gastrointestinal symptoms. Crit Care 2020;24:340. https://doi.org/10.1186/ s13054-020-03034-x.

52. Annweiler C, Sacco G, Salles N, Aquino JP et al. National French survey of Coronavirus disease (COVID-19) symptoms in people aged 70 and over. Clin Infect Dis. 2021;72:490-494. https://doi. org/10.1093/cid/ciaa792.

53. Zhang H, Wang L, Chen Y, Wu Q et al. Outcomes of novel coronavirus disease 2019 (COVID-19) infection in 107 patients with cancer from Wuhan, China. Cancer 2020;126:4023-4031. https://doi.org/10.1002/cncr.33042.

54. Zhang L, Han C, Zhang S, Duan C et al. Diarrhea and altered inflammatory cytokine pattern in severe coronavirus disease 2019: impact on disease course and in-hospital mortality. J Gastroenterol Hepatol 2021;36:421-429. https://doi.org/10.1111/ jgh.15166.

55. Khan S, Ali A, Shi H, Siddique R et al. COVID-19: clinical aspects and therapeutics responses. Saudi Pharm J 2020;28:1004-1008. https://doi.org/10.1016/j.jsps.2020.06.022.

56. Zheng T, Yang C, Wang HY, Chen X et al. Clinical characteristics and outcomes of COVID-19 patients with gastrointestinal symptoms admitted to Jianghan Fangcang Shelter Hospital in Wuhan, China. J Med Virol. 2020;92:2735-2741. https://doi.org/ 10.1002/jmv.26146.
57. Luo S, Deng Z, Zhang X, Pan Z, Xu H. Clinical characteristics and outcomes of 2019 novel coronavirus disease patients presenting with initial gastrointestinal symptoms in Wuhan, China: a retrospective cohort study. J Gastroenterol Hepatol. 2020. https://doi.org/10.1111/jgh.15199.

58. Kaafarani HMA, El Moheb M, Hwabejire JO, Naar L et al. Gastrointestinal complications in critically ill patients with COVID-19. Ann Surg 2020;272:e61-e62. https://doi.org/10. 1097/SLA.0000000000004004.

59. Zhan T, Liu M, Tang Y, Han Z et al. Retrospective analysis of clinical characteristics of 405 patients with COVID-19. J Int Med Res 2020;48:300060520949039. https://doi.org/10.1177/ 0300060520949039 .

60. Díaz LA, García-Salum T, Fuentes-López E, Ferrés M et al. Symptom profiles and risk factors for hospitalization in patients with SARS-CoV-2 and COVID-19: a large cohort from South America. Gastroenterology 2020;159:1148-1150. https://doi.org/10.1053/j.gastro.2020.05.014.

61. Bhayana R, Som A, Li MD, Carey DE et al. Abdominal imaging findings in COVID-19: preliminary observations. Radiology. 2020;297:E207-E215. https://doi.org/10.1148/radiol. 2020201908.

62. García-Azorín D, Trigo J, Talavera B, Martínez-Pías E et al. Frequency and type of red flags in patients with Covid-19 and headache: a series of 104 hospitalized patients. Headache 2020;60:1664-1672. https://doi.org/10.1111/head.13927.

63. Sadeghi A, Eslami P, Dooghaie Moghadam A. Risk factors related to liver injury in non-Intensive Care Unit admitted patients infected with COVID-19: a retrospective study of 102 patients. Caspian J Intern Med 2020;11:520-526. https://doi. org/10.22088/cjim.11.0.520.

64. Chen R, Yu YL, Li W, Liu Y, Lu JX, Chen F et al. Gastrointestinal symptoms associated with unfavorable prognosis of COVID-19 patients: a retrospective study. Front Med (Lausanne) 2020;7:608259. https://doi.org/10.3389/fmed.2020. 608259.

65. Elimian KO, Ochu CL, Ebhodaghe B, Myles P, Crawford EE, Igumbor $\mathrm{E}$ et al. Patient characteristics associated with COVID19 positivity and fatality in Nigeria: retrospective cohort study. BMJ Open 2020;10:e044079. https://doi.org/10.1136/bmjop en-2020-044079.

66. Kim K, Choi JW, Moon J, Akilov H, Tuychiev L, Rakhimov B et al. Clinical features of COVID-19 in Uzbekistan. J Korean Med Sci 2020;35:e404. https://doi.org/10.3346/jkms.2020.35. e404.

67. An P, Chen H, Ren H, Su J, Ji M, Kang J, Jiang X et al. Gastrointestinal symptoms onset in COVID-19 patients in Wuhan, China. Dig Dis Sci. 2020;12:1-10. https://doi.org/10.1007/ s10620-020-06693-6.

68. Ganz-Lord FA, Segal KR, Rinke ML. COVID-19 symptoms, duration, and prevalence among healthcare workers in the New York metropolitan area. Infect Control Hosp Epidemiol 2020;20:1-7. https://doi.org/10.1017/ice.2020.1334.

69. Alizadehsani R, Alizadeh Sani Z, Behjati M, Roshanzamir Z, Hussain $\mathrm{S}$, Abedini $\mathrm{N}$ et al. Risk factors prediction, clinical outcomes, and mortality in COVID-19 patients. J Med Virol 2021;93:2307-2320. https://doi.org/10.1002/jmv.26699.

70. Jiang Y, Abudurexiti S, An MM, Cao D, Wei J, Gong P. Risk factors associated with 28-day all-cause mortality in older severe COVID-19 patients in Wuhan, China: a retrospective observational study. Sci Rep 2020;10:22369. https://doi.org/10.1038/ s41598-020-79508-3.

71. Jiang Y, Han C, Bai T, Zhang S, Song J, Hou X. Gastroenterologists reveal more digestive symptoms in COVID-19 patients than nongastroenterologists in fever clinic. Gastroenterol Res Pract 2020;2020:8853922. https://doi.org/10.1155/2020/8853922. 
72. Xiao F, Tang M, Zheng X, Liu Y, Li X, Shan H. Evidence for gastrointestinal infection of SARS-CoV-2. Gastroenterology 2020;158:1831-1833.e3. https://doi.org/10.1053/j.gastro.2020. 02.055 .

73. Lo IL, Lio CF, Cheong HH, Lei CI, Cheong TH, Zhong X et al. Evaluation of SARS-CoV-2 RNA shedding in clinical specimens and clinical characteristics of 10 patients with COVID-19 in Macau. Int J Biol Sci 2020;16:1698-1707. https://doi.org/ 10.7150/ijbs. 45357.

74. To KK, Tsang OT, Leung WS, Tam AR, Wu TC, Lung DC et al. Temporal profiles of viral load in posterior oropharyngeal saliva samples and serum antibody responses during infection by SARS-CoV-2: an observational cohort study. Lancet Infect Dis 2020;20:565-574. https://doi.org/10.1016/S1473-3099(20) 30196-1.

75. Wu Y, Guo C, Tang L, Hong Z, Zhou J, Dong X et al. Prolonged presence of SARS-CoV-2 viral RNA in faecal samples. Lancet Gastroenterol Hepatol 2020;5:434-435. https://doi.org/ 10.1016/S2468-1253(20)30083-2.

76. Chung M, Bernheim A, Mei X, Zhang N, Huang M, Zeng X et al. CT imaging features of 2019 novel Coronavirus (2019nCoV). Radiology 2020;295:202-207. https://doi.org/10.1148/ radiol.2020200230.

77. Liu Y, Yang Y, Zhang C, Huang F, Wang F, Yuan J et al. Clinical and biochemical indexes from 2019-nCoV infected patients linked to viral loads and lung injury. Sci China Life Sci 2020;63:364-374. https://doi.org/10.1007/s11427-020-1643-8.

78. Lin L, Jiang X, Zhang Z, Huang S, Zhang Z, Fang Z et al. Gastrointestinal symptoms of 95 cases with SARS-CoV-2 infection. Gut 2020;69:997-1001. https://doi.org/10.1136/ gutjnl-2020-321013.

79. Huang C, Wang Y, Li X, Ren L, Zhao J, Hu Y et al. Clinical features of patients infected with 2019 novel coronavirus in Wuhan, China. Lancet 2020;395:497-506. https://doi.org/10. 1016/S0140-6736(20)30183-5.

80. Effenberger M, Grabherr F, Mayr L, Schwaerzler J, Nairz M, Seifert $\mathrm{M}$ et al. Faecal calprotectin indicates intestinal inflammation in COVID-19. Gut. 2020. https://doi.org/10.1136/ gutjnl-2020-321388.

81. Wang F, Wang H, Fan J, Zhang Y, Wang H, Zhao Q. Pancreatic injury patterns in patients with COVID-19 pneumonia. Gastroenterology 2020;S0016-5085:30409-30411. https://doi.org/10. 1053/j.gastro.2020.03.055.

82. Yang X, Yu Y, Xu J, Shu H, Xia J, Liu H et al. Clinical course and outcomes of critically ill patients with SARS-CoV-2 pneumonia in Wuhan, China: a single-centered, retrospective, observational study. Lancet Respir Med 2020;8:475-481. https://doi. org/10.1016/S2213-2600(20)30079-5.

83. Chen N, Zhou M, Dong X, Qu J, Gong F, Han Y et al. Epidemiological and clinical characteristics of 99 cases of 2019 novel coronavirus pneumonia in Wuhan, China: a descriptive study. Lancet 2020;395:507-513. https://doi.org/10.1016/S01406736(20)30211-7.

84. Ping A, Hongbin C, Xiaoda J, Honggang Y. Clinical features of 2019 novel coronavirus pneumonia presented gastrointestinal symptoms but without fever onset. Lancet Preprint. Available at: https://ssrn.com/abstract=3532530. Accessed 13.05.20.

85. Chang D, Lin M, Wei L, Xie L, Zhu G, Dela Cruz CS et al. Epidemiologic and clinical characteristics of novel Coronavirus infections involving 13 patients outside Wuhan, China. JAMA 2020;323:1092-1093. https://doi.org/10.1001/jama.2020.1623.

86. Song F, Shi N, Shan F, Zhang Z, Shen J, Lu H et al. Emerging 2019 novel Coronavirus (2019-nCoV) pneumonia. Radiology 2020;295:210-217. https://doi.org/10.1148/radiol.2020200274.

87. Hu Z, Song C, Xu C, Jin G, Chen Y, Xu X et al. Clinical characteristics of 24 asymptomatic infections with COVID-19 screened among close contacts in Nanjing, China. Sci China Life Sci 2020;63:706-711. https://doi.org/10.1007/s11427-020-1661-4.

88. Luo E, Zhang D, Luo H, Liu B, Zhao K, Zhao Y et al. Treatment efficacy analysis of traditional Chinese medicine for novel coronavirus pneumonia (COVID-19): an empirical study from Wuhan, Hubei Province, China. Chin Med 2020;15:34. https:// doi.org/10.1186/s13020-020-00317-X.

89. Zhao XY, Xu XX, Yin HS, Hu QM, Xiong T, Tang YY et al. Clinical characteristics of patients with 2019 Coronavirus disease in a non-Wuhan area of Hubei Province, China: a retrospective study. BMC Infect Dis 2020;20:311. https://doi.org/10.1186/ s12879-020-05010-w.

90. Duan K, Liu B, Li C, Zhang H, Yu T, Qu J et al. Effectiveness of convalescent plasma therapy in severe COVID-19 patients. Proc Natl Acad Sci USA 2020;117:9490-9496. https://doi.org/ 10.1073/pnas.2004168117.

91. Zheng S, Fan J, Yu F, Feng B, Lou B, Zou Q et al. Viral load dynamics and disease severity in patients infected with SARSCoV-2 in Zhejiang province, China, January-March 2020: retrospective cohort study. BMJ 2020;369:m1443. https://doi.org/ 10.1136/bmj.m1443.

92. Xu X, Yu C, Qu J, Zhang L, Jiang S, Huang D et al. Imaging and clinical features of patients with 2019 novel coronavirus SARSCoV-2. Eur J Nucl Med Mol Imaging 2020;47:1275-1280. https://doi.org/10.1007/s00259-020-04735-9.

93. Shi $\mathrm{H}, \mathrm{Han} \mathrm{X}$, Jiang $\mathrm{N}$ et al. Radiological findings from 81 patients with COVID-19 pneumonia in Wuhan, China: a descriptive study. Lancet Infect Dis 2020;20:425-434. https://doi.org/ 10.1016/S1473-3099(20)30086-4.

94. Cheung KS, Hung IF, Chan PP, Lung KC, Tso E, Liu R et al. Gastrointestinal manifestations of SARS-CoV-2 infection and virus load in Fecal samples from the Hong Kong cohort and systematic review and meta-analysis. Gastroenterology 2020;S0016-5085:30448. https://doi.org/10.1053/j.gastro.2020. 03.065 .

95. Chen Q, Quan B, Li X, Gao G et al. A report of clinical diagnosis and treatment of nine cases of coronavirus disease 2019. J Med Virol 2020;92:683-687. https://doi.org/10.1002/jmv.25755.

96. Chen Y, Chen L, Deng Q, Zhang G, Wu K, Ni L et al. The presence of SARS-CoV-2 RNA in Feces of COVID-19 patients. $J$ Med Virol 2020;92:833-840. https://doi.org/10.1002/jmv.25825.

97. Conway J, Gould A, Westley R, Raju SA et al. Clinical characteristics and progression of COVID-19 confirmed cases admitted to a single British clinical centre-a brief case series report. Int J Clin Pract 2020;31:e13807. https://doi.org/10.1111/ijcp.13807.

98. Martin TA, Wan DW, Hajifathalian K, Tewani S et al. Gastrointestinal bleeding in patients with Coronavirus disease 2019: a matched case-control study. Am J Gastroenterol. 2020;115:16091616. https://doi.org/10.14309/ajg.0000000000000805.

99. Aumpan N, Nunanan P, Vilaichone RK. Gastrointestinal manifestation as clinical predictor of severe COVID-19: a retrospective experience and literature review of COVID-19 in Association of Southeast Asian Nations (ASEAN). JGH Open 2020;4:10961101. https://doi.org/10.1002/jgh3.12394.

100. Xie S, Zhang G, Yu H, Wang J et al. The epidemiologic and clinical features of suspected and confirmed cases of imported 2019 novel coronavirus pneumonia in north Shanghai, China. Ann Transl Med. 2020;8:637. https://doi.org/10.21037/atm-20-2119.

101. Zuo T, Zhang F, Lui GCY, Yeoh YK et al. Alterations in Gut microbiota of patients with COVID-19 during time of hospitalization. Gastroenterology. 2020;159:944-955.e8. https://doi.org/ 10.1053/j.gastro.2020.05.048.

102. Shao L, Li X, Zhou Y, Yu Y et al. Novel insights into illness progression and risk profiles for mortality in non-survivors of COVID-19. Front Med (Lausanne) 2020;7:246. https://doi.org/ 10.3389/fmed.2020.00246. 
103. Liu BM, Yang QQ, Zhao LY, Xie W, Si XY. Epidemiological characteristics of COVID-19 patients in convalescence period. Epidemiol Infect 2020;148:e108. https://doi.org/10.1017/S0950 268820001181.

104. Gu S, Chen Y, Wu Z, Chen Y et al. Alterations of the Gut microbiota in patients with COVID-19 or H1N1 influenza. Clin Infect Dis. 2020;4:709. https://doi.org/10.1093/cid/ciaa709.

105. Liu T, Zhang J, Yang Y, Ma H et al. The role of interleukin-6 in monitoring severe case of coronavirus disease 2019. EMBO Mol Med 2020;12:e12421. https://doi.org/10.15252/emmm.20201 2421.

106. Chen M, An W, Xia F, Yang P et al. Clinical characteristics of rehospitalized patients with COVID-19 in China. J Med Virol 2020;92:2146-2151. https://doi.org/10.1002/jmv.26002.

107. Park SK, Lee CW, Park DI, Woo HY et al. Detection of SARSCoV-2 in Fecal samples from patients with asymptomatic and mild COVID-19 in Korea. Clin Gastroenterol Hepatol. 2020. https://doi.org/10.1016/j.cgh.2020.06.005.

108. Rivera-Izquierdo M, Valero-Ubierna MDC, Martínez-Diz S, Fernández-García MÁ et al. Clinical factors, preventive behaviours and temporal outcomes associated with COVID-19 infection in health professionals at a Spanish Hospital. Int J Environ Res Public Health 2020;17:4305. https://doi.org/10.3390/ijerp h17124305.

109. Zuo T, Zhan H, Zhang F, Liu Q et al. Alterations in Fecal fungal microbiome of patients with COVID-19 during time of hospitalization until discharge. Gastroenterology. 2020;159:1302-1310. e5. https://doi.org/10.1053/j.gastro.2020.06.048

110. Tsibouris P, Ekmektzoglou K, Agorogianni A, Kalantzis C et al. Gastrointestinal involvement in COVID-19 patients: a retrospective study from a Greek COVID-19 referral hospital. Ann Gastroenterol. 2020;33:465-472. https://doi.org/10.20524/aog.2020. 0514.

111. Papa A, Covino M, Pizzolante F, Miele L et al. Gastrointestinal symptoms and digestive comorbidities in an Italian cohort of patients with COVID-19. Eur Rev Med Pharmacol Sci. 2020;24:7506-7511. https://doi.org/10.26355/eurrev_202007_ 21923.

112. Uzzan M, Soudan D, Peoc'h K, Weiss E et al. Patients with COVID-19 present with low plasma citrulline concentrations that associate with systemic inflammation and gastrointestinal symptoms. Dig Liver Dis 2020;52:1104-1105. https://doi.org/ 10.1016/j.dld.2020.06.042.

113. Shao T, Tong Y, Lu S, Jeyarajan AJ et al. $\gamma$-Glutamyltransferase elevations are frequent in patients with COVID-19: a clinical epidemiologic study. Hepatol Commun. 2020;4:1744-1750. https:// doi.org/10.1002/hep4.1576.

114. Zuo T, Liu Q, Zhang F, Lui GC et al. Depicting SARS-CoV-2 faecal viral activity in association with gut microbiota composition in patients with COVID-19. Gut 2021;70:276-284. https:// doi.org/10.1136/gutjnl-2020-322294.

115. McNabb-Baltar J, Jin DX, Grover AS, Redd WD et al. Lipase elevation in patients with COVID-19. Am J Gastroenterol 2020;115:1286-1288. https://doi.org/10.14309/ajg.0000000000 000732

116. Xu J, Chu M, Zhong F, Tan X et al. Digestive symptoms of COVID-19 and expression of ACE2 in digestive tract organs. Cell Death Discov 2020;6:76. https://doi.org/10.1038/ s41420-020-00307-w.

117. D'Ettorre G, Ceccarelli G, Marazzato M, Campagna G. Challenges in the management of SARS-CoV2 infection: the role of oral bacteriotherapy as complementary therapeutic strategy to avoid the progression of COVID-19. Front Med (Lausanne) 2020;7:389. https://doi.org/10.3389/fmed.2020.00389.

118. Chen H, Guo J, Wang C, Luo F, Yu X, Zhang W et al. Clinical characteristics and intrauterine vertical transmission potential of
COVID-19 infection in nine pregnant women: a retrospective review of medical records. Lancet 2020;7:809-815. https://doi. org/10.1016/S0140-6736(20)30360-3.

119. Xu XW, Wu XX, Jiang XG, Xu KJ, Ying LJ, Ma CL et al. Clinical findings in a group of patients infected with the 2019 novel coronavirus (SARS-Cov-2) outside of Wuhan, China: retrospective case series. BMJ 2020;19:m606. https://doi.org/10.1136/ bmj.m606.

120. Ghoshal UC, Ghoshal U, Mathur A, Singh RK, Nath A, Garg A et al. The spectrum of gastrointestinal symptoms in patients with Coronavirus disease-19: predictors, relationship with disease severity, and outcome. Clin Transl Gastroenterol 2020;11:e00259. https://doi.org/10.14309/ctg.0000000000 000259.

121. Hong L, Ye E, Sun G, Wang X, Zhang S, Wu Y et al. Clinical and radiographic characteristics, management and shortterm outcomes of patients with COVID-19 in Wenzhou, China. BMC Infect Dis 2020;20:841. https://doi.org/10.1186/ s12879-020-05528-z.

122. Kashefizadeh A, Ohadi L, Golmohammadi M, Araghi F, Dadkhahfar S, Kiani A et al. Clinical features and short-term outcomes of COVID-19 in Tehran, Iran: an analysis of mortality and hospital stay. Acta Biomed 2020;91:e2020147. https://doi. org/10.23750/abm.v91i4.10206.

123. Haghighi-Morad M, Alavi Darazam I, Bahrami-Moltagh H, Amerifar M, Zamani N, Hassanian-Moghaddam H. Atypical presentation of COVID-19; an observational retrospective study. BMC Infect Dis 2020;20:870. https://doi.org/10.1186/ s12879-020-05617-Z.

124. Shao S, Zhao Z, Wang F, Chang D, Liu Y, Liu S et al. Risk factors associated with disease aggravation among 126 hospitalized patients with COVID-19 in different places in China: a retrospective observational study. Medicine (Baltimore) 2020;99:e22971. https://doi.org/10.1097/MD.0000000000022971.

125. Sun Y, Zhao R, Hu Z, Wang W, Wang S, Gao L et al. Differences in the clinical and hematological characteristics of COVID19 patients with and without type 2 diabetes. J Diabetes Res 2020;2020:1038585. https://doi.org/10.1155/2020/1038585.

126. Wan Y, Li J, Shen L, Zou Y, Hou L, Zhu L et al. Enteric involvement in hospitalised patients with COVID-19 outside Wuhan. Lancet Gastroenterol Hepatol 2020;5:534-535.

127. Henry BM, de Oliveira MHS, Benoit J, Lippi G. Gastrointestinal symptoms associated with severity of coronavirus disease 2019 (COVID-19): a pooled analysis. Intern Emerg Med. 2020. https:// doi.org/10.1007/s11739-020-02329-9.

128. Dong ZY, Xiang BJ, Jiang M, Sun MJ, Dai C. The prevalence of gastrointestinal symptoms, abnormal liver function, digestive system disease and liver disease in COVID-19 infection: a systematic review and meta-analysis. J Clin Gastroenterol 2021;55:67-76. https://doi.org/10.1097/MCG.0000000000 001424.

129. Leung WK, To KF, Chan PK, Chan HL, Wu AK, Lee $\mathrm{N}$ et al. Enteric involvement of severe acute respiratory syndrome-associated coronavirus infection. Gastroenterology 2003;125:10111017. https://doi.org/10.1016/s0016-5085(03)01215-0.

130. Hui DSC, Zumla A. Severe acute respiratory syndrome: historical, epidemiologic, and clinical features. Infect Dis Clin North Am 2019;33:869-889. https://doi.org/10.1016/j.idc.2019.07.001.

131. El Moheb M, Naar L, Christensen MA, Kapoen C, Maurer LR, Farhat $\mathrm{M}$ et al. Gastrointestinal complications in critically ill patients with and without COVID-19. JAMA. 2020;324:18991901. https://doi.org/10.1001/jama.2020.19400.

132. Mansourian M, Ghandi Y, Habibi D, Mehrabi S. COVID-19 infection in children: a systematic review and meta-analysis of clinical features and laboratory findings. Arch Pediatr. 2021. https://doi.org/10.1016/j.arcped.2020.12.008. 
133. Ludvigsson JF. Systematic review of COVID-19 in children shows milder cases and a better prognosis than adults. Acta Paediatr 2020;109:1088-1095. https://doi.org/10.1111/apa. 15270.

134. Heald-Sargent T, Muller WJ, Zheng X, Rippe J, Patel AB, Kociolek LK. Age-related differences in nasopharyngeal severe acute respiratory syndrome Coronavirus 2 (SARS-CoV-2) levels in patients with mild to moderate Coronavirus disease 2019 (COVID-19). JAMA Pediatr 2020;174:902-903. https://doi.org/ 10.1001/jamapediatrics.2020.3651.

135. Giacomet V, Barcellini L, Stracuzzi M, Longoni E et al. COVID19 Pediatric network. Gastrointestinal symptoms in severe COVID-19 children. Pediatr Infect Dis J. 2020;39:e317-e320. https://doi.org/10.1097/INF.0000000000002843.

136. Garazzino S, Montagnani $\mathrm{C}$, Donà $\mathrm{D}$, Meini $\mathrm{A}$, et al. Italian SITIP-SIP Pediatric Infection Study Group; Italian SITIP-SIP SARS-CoV-2 paediatric infection study group*. Multicentre Italian study of SARS-CoV-2 infection in children and adolescents, preliminary data as at 10 April 2020. Euro Surveill. 2020;25:2000600. https://doi.org/10.2807/1560-7917.ES.2020. 25.18.2000600.

137. Du H, Dong X, Zhang JJ, Cao YY et al. Clinical characteristics of 182 pediatric COVID-19 patients with different severities and allergic status. Allergy. 2021;76:510-532. https://doi.org/ 10.1111/all.14452.

138. Gaborieau L, Delestrain C, Bensaid P, Vizeneux A et al. Epidemiology and clinical presentation of children hospitalized with SARS-CoV-2 infection in suburbs of Paris. J Clin Med. 2020;9:2227. https://doi.org/10.3390/jcm9072227.

139. Guo CX, He L, Yin JY, Meng XG et al. Epidemiological and clinical features of pediatric COVID-19. BMC Med. 2020;18:250. https://doi.org/10.1186/s12916-020-01719-2.

140. Rabha AC, Oliveira Junior FI, Oliveira TA, Cesar RG, Fongaro $\mathrm{G}$, Mariano RF et al. Clinical manifestations of children and adolescents with covid-19: report of the first 115 cases from Sabará Hospital Infantil. Rev Paul Pediatr 2020;39:e2020305. https:// doi.org/10.1590/1984-0462/2021/39/2020305.

141. Bayesheva D, Boranbayeva R, Turdalina B, Fakhradiyev I, Saliev T, Tanabayeva $\mathrm{S}$ et al. COVID-19 in the paediatric population of Kazakhstan. Paediatr Int Child Health. 2020. https://doi.org/10. 1080/20469047.2020.1857101.

142. Parri N, Lenge M, Buonsenso D. Coronavirus Infection in Pediatric Emergency Departments (CONFIDENCE) Research Group. Children with Covid-19 in Pediatric Emergency Departments in Italy. N Engl J Med 2020;383:187-190. https://doi.org/10.1056/ NEJMc2007617.

143. CDC COVID-19 Response Team. Coronavirus disease 2019 in Children-United States, February 12-April 2, 2020. MMWR Morb Mortal Wkly Rep. 2020;69:422-426. https://doi.org/10. 15585/mmwr.mm6914e4.

144. DeBiasi RL, Song X, Delaney M, Bell M, Smith K, Pershad J et al. Severe Coronavirus disease-2019 in children and young adults in the Washington, DC, Metropolitan Region. J Pediatr 2020;223:199-203.e1. https://doi.org/10.1016/j.jpeds.2020.05. 007.

145. Lu X, Zhang L, Du H, Zhang J, Li YY, Qu J et al. Chinese Pediatric Novel Coronavirus Study Team. SARS-CoV-2 infection in children. N Engl J Med 2020;382:1663-1665. https://doi.org/10. 1056/NEJMc2005073.

146. Armann JP, Diffloth N, Simon A, Doenhardt M, Hufnagel M, Trotter A et al. Hospital admission in children and adolescents with COVID-19. Dtsch Arztebl Int 2020;117:373-374. https:// doi.org/10.3238/arztebl.2020.0373.

147. Wu H, Zhu H, Yuan C, Yao C, Luo W, Shen X et al. Clinical and immune features of hospitalized pediatric patients with Coronavirus disease 2019 (COVID-19) in Wuhan, China. JAMA Netw
Open 2020;3:e2010895. https://doi.org/10.1001/jamanetwor kopen.2020.10895.

148. Zhen-Dong Y, Gao-Jun Z, Run-Ming J, Zhi-Sheng L, Zong-Qi D, Xiong $\mathrm{X}$ et al. Clincal and transmission dynamics characteristics of 406 children with coronavirus disease 2019 in China: a review. J Infect. 2020;81:e11-e15. https://doi.org/10.1016/j.jinf.2020.04. 030.

149. Feldstein LR, Rose EB, Horwitz SM, Collins JP, Newhams MM, Son MBF et al. Overcoming COVID-19 Investigators CDC COVID-19 Response Team. Multisystem inflammatory syndrome in U.S. children and adolescents. $N$ Engl J Med. 2020;383:334-346. https://doi.org/10.1056/NEJMoa2021680.

150. Godfred-Cato S, Bryant B, Leung J, Oster ME, Conklin L, Abrams J et al. California MIS-C Response Team. COVID19 -associated multisystem inflammatory syndrome in children-United States, March-July 2020. Morb Mortal Wkly Rep 2020;69:1074-1080. https://doi.org/10.15585/mmwr.mm6932e2.

151. Guo CX, He L, Yin JY, Meng XG, Tan W, Yang GP et al. Epidemiological and clinical features of pediatric COVID-19. BMC Med. 2020;18:250. https://doi.org/10.1186/s12916-020-01719-2.

152. Liu W, Zhang Q, Chen J, Xiang R, Song H, Shu S et al. Detection of Covid-19 in children in early January 2020 in Wuhan, China. N Engl J Med. 2020;382:1370-1371. https://doi.org/10. 1056/NEJMc2003717.

153. Xia W, Shao J, Guo Y, Peng X, Li Z, Hu D. Clinical and CT features in pediatric patients with COVID-19 infection: different points from adults. Pediatr Pulmonol 2020;55:1169-1174. https://doi.org/10.1002/ppul.24718.

154. Tan YP, Tan BY, Pan J, Wu J, Zeng SZ, Wei HY. Epidemiologic and clinical characteristics of 10 children with coronavirus disease 2019 in Changsha, China. J Clin Virol 2020;127:104353. https://doi.org/10.1016/j.jcv.2020.104353.

155. Xu Y, Li X, Zhu B, Liang H, Fang C, Gong Y et al. Characteristics of pediatric SARS-CoV-2 infection and potential evidence for persistent Fecal viral shedding. Nat Med 2020;26:502-505. https://doi.org/10.1038/s41591-020-0817-4.

156. Zachariah P, Johnson CL, Halabi KC, Ahn D et al. Columbia Pediatric COVID-19 Management Group. Epidemiology, clinical features, and disease severity in patients with Coronavirus disease 2019 (COVID-19) in a Children's Hospital in New York City, New York. JAMA Pediatr 2020;174:e202430. https://doi. org/10.1001/jamapediatrics.2020.2430.

157. Liu X, Tang J, Xie R, Li W et al. Clinical and epidemiological features of 46 children $<1$ year old with Coronavirus disease 2019 in Wuhan, China: a descriptive study. J Infect Dis. 2020;222:1293-1297. https://doi.org/10.1093/infdis/jiaa472. Erratum.In:JInfectDis.2021Feb13;223(3):540.

158. Xiong XL, Wong KK, Chi SQ, Zhou AF et al. Comparative study of the clinical characteristics and epidemiological trend of 244 COVID-19 infected children with or without GI symptoms. Gut. 2021;70:436-438. https://doi.org/10.1136/gutjnl-2020-321486.

159. Chen Z, Tong L, Zhou Y, Hua C et al. Childhood COVID19: a multicentre retrospective study. Clin Microbiol Infect 2020;26:1260.e1-1260.e4. https://doi.org/10.1016/j.cmi.2020. 06.015 .

160. Kainth MK, Goenka PK, Williamson KA, Fishbein JS et al. Northwell Health Covid-19 research consortium. Early experience of COVID-19 in a US Children's Hospital. Pediatrics 2020;146:e2020003186. https://doi.org/10.1542/peds. 2020-003186.

161. Prata-Barbosa A, Lima-Setta F, Santos GRD, Lanziotti VS et al. Brazilian research network in pediatric intensive care, (BRnetPIC). Pediatric patients with COVID-19 admitted to intensive care units in Brazil: a prospective multicenter study. J Pediatr (Rio J) 2020;96:582-592. https://doi.org/10.1016/j.jped.2020.07. 002 . 
162. García-Salido A, de Carlos Vicente JC, Belda Hofheinz S, Balcells Ramírez J, Slöcker Barrio M, Leóz Gordillo I et al. Spanish Pediatric Intensive Care Society working group on SARS-CoV-2 infection. Severe manifestations of SARS-CoV-2 in children and adolescents: from COVID-19 pneumonia to multisystem inflammatory syndrome: a multicentre study in pediatric intensive care units in Spain. Crit Care 2020;24:666. https://doi.org/10.1186/ s13054-020-03332-4.

163. Lima-Setta F, Magalhães-Barbosa MC, Rodrigues-Santos G, Figueiredo EADN, Jacques ML, Zeitel RS et al. Brazilian research network in pediatric intensive care (BRnet-PIC). Multisystem inflammatory syndrome in children (MIS-C) during SARS-CoV-2 pandemic in Brazil: a multicenter, prospective cohort study. J Pediatr (Rio J). 2020. https://doi.org/10.1016/j. jped.2020.10.008.

164. Carbajal R, Lorrot M, Levy Y, Grimprel E, Lecarpentier T, Heritier $\mathrm{S}$ et al. Multisystem inflammatory syndrome in children rose and fell with the first wave of the COVID-19 pandemic in France. Acta Paediatr 2021;110:922-932. https://doi.org/10.1111/apa. 15667.

165. Velasco Rodríguez-Belvís M, Medina Benítez E, García Tirado D, Herrero Álvarez M, González JD. SARS-CoV-2 infection in infants aged 28 days and younger. A multicentre case series. $A n$ Pediatr (Engl Ed). 2020. https://doi.org/10.1016/j.anpede.2020. 12.005 .

166. Tagarro A, Epalza C, Santos M, Sanz-Santaeufemia FJ, Otheo E, Moraleda $\mathrm{C}$ et al. Screening and severity of Coronavirus disease 2019 (COVID-19) in children in Madrid, Spain. JAMA Pediatr. 2020. https://doi.org/10.1001/jamapediatrics.2020.1346.

167. Han YN, Feng ZW, Sun LN, Ren XX, Wang H, Xue YM et al. A comparative-descriptive analysis of clinical characteristics in 2019-coronavirus-infected children and adults. J Med Virol 2020;92:1596-1602. https://doi.org/10.1002/jmv.25835.

168. Chen J, Zhang ZZ, Chen YK, Long QX, Tian WG, Deng HJ et al. The clinical and immunological features of pediatric COVID-19 patients in China. Genes Dis 2020;7:535-541. https://doi.org/10. 1016/j.gendis.2020.03.008.

169. Shen Q, Guo W, Guo T, Li J, He W, Ni S et al. Novel coronavirus infection in children outside of Wuhan, China. Pediatr Pulmonol 2020;55:1424-1429. https://doi.org/10.1002/ppul.24762.

170. Chiotos K, Bassiri H, Behrens EM, Blatz AM, Chang J, Diorio $\mathrm{C}$ et al. Multisystem inflammatory syndrome in children during the Coronavirus 2019 pandemic: a case series. J Pediatric Infect Dis Soc 2020;9:393-398. https://doi.org/10.1093/jpids/piaa069.

171. Wu Q, Xing Y, Shi L, Li W, Gao Y, Pan S et al. Coinfection and other clinical characteristics of COVID-19 in children. Pediatrics 2020;146:e20200961. https://doi.org/10.1542/peds.2020-0961.

172. Denina M, Scolfaro C, Silvestro E, Pruccoli G, Mignone F, Zoppo $\mathrm{M}$ et al. Lung ultrasound in children with COVID-19. Pediatrics 2020;146:e20201157. https://doi.org/10.1542/peds. 2020-1157.

173. Musolino AM, Supino MC, Buonsenso D, Ferro V, Valentini P, Magistrelli A et al. Roman Lung Ultrasound Study Team for Pediatric COVID-19 (ROMULUS COVID Team). Lung ultrasound in children with COVID-19: preliminary findings. Ultrasound Med Biol 2020;46:2094-2098. https://doi.org/10.1016/j. ultrasmedbio.2020.04.026.

174. Posfay-Barbe KM, Wagner N, Gauthey M, Moussaoui D, Loevy N, Diana A et al. COVID-19 in children and the dynamics of infection in families. Pediatrics 2020;146:e20201576. https://doi. org/10.1542/peds.2020-1576.

175. Miller J, Cantor A, Zachariah P, Ahn D, Martinez M et al. Gastrointestinal symptoms as a major presentation component of a novel multisystem inflammatory syndrome in children that is related to Coronavirus disease 2019: a single center experience of 44 cases. Gastroenterology. 2020;159:1571-1574.e2. https:// doi.org/10.1053/j.gastro.2020.05.079.

176. Hrusak O, Kalina T, Wolf J, Balduzzi A, Provenzi M, Rizzari C et al. Flash survey on severe acute respiratory syndrome coronavirus-2 infections in paediatric patients on anticancer treatment. Eur J Cancer 2020;132:11-16. https://doi.org/10.1016/j.ejca. 2020.03.021.

177. Soltani J, Sedighi I, Shalchi Z, Sami G, Moradveisi B, Nahidi S. Pediatric coronavirus disease 2019 (COVID-19): an insight from west of Iran. North Clin Istanb 2020;7:284-291. https://doi.org/ 10.14744/nci.2020.90277.

178. Calinescu AM, Vidal I, Grazioli S, Lacroix L, Wildhaber BE. Beware of too aggressive approach in children with acute abdomen during COVID-19 outbreak! Ann Surg 2020;272:e244e245. https://doi.org/10.1097/SLA.0000000000004100.

179. Sun D, Chen X, Li H, Lu XX, Xiao H, Zhang FR et al. SARSCoV-2 infection in infants under 1 year of age in Wuhan City, China. World J Pediat 2020;16:260-266. https://doi.org/10.1007/ s12519-020-00368-y.

180. Ji LN, Chao S, Wang YJ, Li XJ, Mu XD, Lin MG et al. Clinical features of pediatric patients with COVID-19: a report of two family cluster cases. World J Pediatr. 2020;16:267-270. https:// doi.org/10.1007/s12519-020-00356-2.

181. Xing YH, Ni W, Wu Q, Li WJ, Li GJ, Wang WD et al. Prolonged viral shedding in feces of pediatric patients with coronavirus disease 2019. J Microbiol Immunol Infect 2020;53:473-480. https:// doi.org/10.1016/j.jmii.2020.03.021.

182. Sun D, Li H, Lu XX, Xiao H, Ren J, Zhang FR et al. Clinical features of severe pediatric patients with coronavirus disease 2019 in Wuhan: a single center's observational study. World J Pediatr 2020;16:251-259. https://doi.org/10.1007/s12519-020-00354-4.

183. Ibrahim LF, Tosif S, McNab S, Hall S, Lee HJ, Lewena S, Daley AJ, Crawford NW, Steer AC, Bryant PA, Babl FE. SARS-CoV-2 testing and outcomes in the first 30 days after the first case of COVID-19 at an Australian children's hospital. Emerg Med Australa. 2020;32:801-808. https://doi.org/10.1111/1742-6723. 13550.

184. Belhadjer Z, Méot M, Bajolle F, Khraiche D, Legendre A, Abakka $S$ et al. Acute heart failure in multisystem inflammatory syndrome in children in the context of global SARS-CoV-2 pandemic. Circulation 2020;142:429-436. https://doi.org/10.1161/ CIRCULATIONAHA.120.048360.

185. Toubiana J, Poirault C, Corsia A, Bajolle F, Fourgeaud J, Angoulvant $\mathrm{F}$ et al. Kawasaki-like multisystem inflammatory syndrome in children during the covid-19 pandemic in Paris, France: prospective observational study. BMJ 2020;369:2094. https://doi. org/10.1136/bmj.m2094.

186. Licciardi F, Pruccoli G, Denina M, Parodi E, Taglietto M, Rosati $\mathrm{S}$ et al. SARS-CoV-2-induced Kawasaki-like hyperinflammatory syndrome: a novel COVID phenotype in children. Pediatrics. 2020;146:e20201711. https://doi.org/10.1542/peds.2020-1711.

187. Zheng F, Liao C, Fan QH, Chen HB, Zhao XG, Xie ZG et al. Clinical characteristics of children with Coronavirus disease 2019 in Hubei, China. Curr Med Sci. 2020;40:275-280. https:// doi.org/10.1007/s11596-020-2172-6.

188. See KC, Liew SM, Ng DCE, Chew EL, Khoo EM, Sam CH et al. COVID-19: four paediatric cases in Malaysia. Int J Infect Dis. 2020;94:125-127. https://doi.org/10.1016/j.ijid.2020.03.049.

189. Cai X, Ma Y, Li S, Chen Y, Rong Z, Li W. Clinical characteristics of 5 COVID-19 cases with non-respiratory symptoms as the first manifestation in children. Front Pediatr 2020;8:258. https://doi. org/10.3389/fped.2020.00258.

190. Korkmaz MF, Türe E, Dorum BA, Kılıç ZB. The epidemiological and clinical characteristics of 81 children with COVID-19 in a pandemic hospital in turkey: an observational cohort study. 
J Korean Med Sci. 2020;35:e236. https://doi.org/10.3346/jkms. 2020.35.e236.

191. Wolfler A, Mannarino S, Giacomet V, Camporesi A, Zuccotti G. Acute myocardial injury: a novel clinical pattern in children with COVID-19. Lancet Child Adolesc Health. 2020;4:e26-e27. https://doi.org/10.1016/S2352-4642(20)30168-1.

192. Qiu H, Wu J, Hong L, Luo Y, Song Q, Chen D. Clinical and epidemiological features of 36 children with coronavirus disease 2019 (COVID-19) in Zhejiang, China: an observational cohort study. Lancet Infect Dis. 2020;20:689-696. https://doi.org/10. 1016/S1473-3099(20)30198-5.

193. Shekerdemian LS, Mahmood NR, Wolfe KK, Riggs BJ, Ross $\mathrm{CE}, \mathrm{McKiernan} \mathrm{CA}$ et al. International COVID-19 PICU collaborative. Characteristics and outcomes of children with Coronavirus disease 2019 (COVID-19) infection admitted to US and Canadian Pediatric Intensive Care Units. JAMA Pediatr. 2020;174:868-873. https://doi.org/10.1001/jamapediatrics.2020. 1948.

194. Peng H, Gao P, Xu Q, Liu M, Peng J, Wang Y, Xu H. Coronavirus disease 2019 in children: characteristics, antimicrobial treatment, and outcomes. J Clin Virol. 2020;128:104425. https://doi. org/10.1016/j.jcv.2020.104425.

195. Marlais M, Wlodkowski T, Vivarelli M, Pape L, Tönshoff B, Schaefer $\mathrm{F}$ et al. The severity of COVID-19 in children on immunosuppressive medication. Lancet Child Adolesc Health. 2020;4:e17-e18. https://doi.org/10.1016/S2352-4642(20) 30145-0.

196. Ma H, Hu J, Tian J, Zhou X, Li H, Laws MT et al. A singlecenter, retrospective study of COVID-19 features in children: a descriptive investigation. BMC Med. 2020;18:123. https://doi. org/10.1186/s12916-020-01596-9.

197. Li Y, Wang H, Wang F, Du H, Liu X, Chen P et al. Comparison of hospitalized patients with pneumonia caused by COVID19 and influenza A in children under 5 years. Int J Infect Dis. 2020;98:80-83. https://doi.org/10.1016/j.ijid.2020.06.026.

198. Blondiaux E, Parisot P, Redheuil A, Tzaroukian L, Levy Y, Sileo $\mathrm{C}$ et al. Cardiac MRI in children with multisystem inflammatory syndrome associated with COVID-19. Radiology. 2020;297:E283-E288. https://doi.org/10.1148/radiol.20202 02288.

199. Waltuch T, Gill P, Zinns LE, Whitney R, Tokarski J, Tsung JW et al. Features of COVID-19 post-infectious cytokine release syndrome in children presenting to the emergency department. Am J Emerg Med. 2020;38:2246.e3-2246.e6. https://doi.org/10. 1016/j.ajem.2020.05.058.

200. Dufort EM, Koumans EH, Chow EJ, Rosenthal EM, Muse A, Rowlands J et al. New York State and Centers for Disease Control and Prevention Multisystem Inflammatory Syndrome in Children Investigation Team. Multisystem inflammatory syndrome in children in New York State. N Engl J Med. 2020;383:347-358. https://doi.org/10.1056/NEJMoa2021756.

201. Kainth MK, Goenka PK, Williamson KA, Fishbein JS, Subramony A, Barone S et al. Northwell Health Covid-19 research consortium. Early experience of COVID-19 in a US Children's Hospital. Pediatrics 2020;146:e2020003186. https://doi.org/10. 1542/peds.2020-003186.

202. Steinberger S, Lin B, Bernheim A, Chung M, Gao Y, Xie Z et al. CT features of Coronavirus disease (COVID-19) in 30 pediatric patients. Am J Roentgenol 2020;215:1303-1311. https://doi.org/ 10.2214/AJR.20.23145.

203. Zhang L, Huang S. Clinical features of 33 cases in children infected with SARS-CoV-2 in Anhui Province, China-a Multi-Center Retrospective Cohort Study. Front Public Health 2020;8:255. https://doi.org/10.3389/fpubh.2020.00255.

204. Brisca G, Ferretti M, Sartoris G, Damasio MB, Buffoni I, Pirlo D et al. The early experiences of a single tertiary Italian emergency department treating COVID-19 in children. Acta Paediatr 2020;109:2155-2156. https://doi.org/10.1111/apa.15451.

205. Fakiri KE, Nassih H, Sab IA, Draiss G, Bouskraoui M. Epidemiology and clinical features of Coronavirus disease 2019 in Moroccan children. Indian Pediatr 2020;57:808-810. https://doi. org/10.1007/s13312-020-1958-8.

206. Mannheim J, Gretsch S, Layden JE, Fricchione MJ. Characteristics of hospitalized pediatric Coronavirus disease 2019 cases in Chicago, Illinois, March-April 2020. J Pediatric Infect Dis Soc 2020;9:519-522. https://doi.org/10.1093/jpids/piaa070.

207. Hua CZ, Miao ZP, Zheng JS, Huang Q, Sun QF, Lu HP et al. Epidemiological features and viral shedding in children with SARSCoV-2 infection. J Med Virol 2020;92:2804-2812. https://doi. org/10.1002/jmv.26180.

208. De Ceano-Vivas M, Martín-Espín I, Del Rosal T, Bueno-Barriocanal M, Plata-Gallardo M, Ruiz-Domínguez JA et al. SARSCoV-2 infection in ambulatory and hospitalised Spanish children. Arch Dis Child 2020;105:808-809. https://doi.org/10.1136/archd ischild-2020-319366.

209. Bai K, Liu W, Liu C, Fu Y, Hu J, Qin Y et al. Clinical analysis of 25 COVID-19 infections in children. Pediatr Infect Dis J 2020;39:e100-e103. https://doi.org/10.1097/INF.0000000000 002740 .

210. De Ioris MA, Scarselli A, Ciofi Degli Atti ML, Ravà L, Smarrazzo A, Concato $\mathrm{C}$ et al. Dynamic viral severe acute respiratory syndrome Coronavirus 2 RNA shedding in children: preliminary data and clinical consideration from a Italian Regional Center. J Pediatric Infect Dis Soc 2020;9:366-369. https://doi. org/10.1093/jpids/piaa065.

211. Zhang C, Gu J, Chen Q, Deng N, Li J, Huang L et al. Clinical and epidemiological characteristics of pediatric SARSCoV-2 infections in China: a multicenter case series. PLoS Med 2020;17:e1003130. https://doi.org/10.1371/journal.pmed.10031 30.

212. Ma X, Su L, Zhang Y, Zhang X, Gai Z, Zhang Z. Do children need a longer time to shed SARS-CoV-2 in stool than adults? $J$ Microbiol Immunol Infect 2020;53:373-376. https://doi.org/10. 1016/j.jmii.2020.03.010.

213. Zhao D, Yao F, Wang L, Zheng L, Gao Y, Ye J et al. A comparative study on the clinical features of COVID-19 pneumonia to other pneumonias. Clin Infect Dis. 2020. https://doi.org/10.1093/ $\mathrm{cid} / \mathrm{ciaa} 247$.

214. Sun J, Aghemo A, Forner A, Valenti L. COVID-19 and liver disease. Liver Int 2020;40:1278-1281. https://doi.org/10.1111/ liv. 14470.

215. Ding ZY, Li GX, Chen L, Shu C, Song J, Wang W et al. Association of liver abnormalities with in-hospital mortality in patients with COVID-19. J Hepatol 2021;74:1295-1302. https://doi.org/ 10.1016/j.jhep.2020.12.012.

216. Satapathy SK, Roth NC, Kvasnovsky C, Hirsch JS, Trindade AJ, Molmenti E et al. Risk factors and outcomes for acute-on-chronic liver failure in COVID-19: a large multi-center observational cohort study. Hepatol Int 2021;7:1-14. https://doi.org/10.1007/ s12072-021-10181-y.

217. Liu F, Long X, Zhang B, Zhang W, Chen X, Zhang Z. ACE2 expression in pancreas may cause pancreatic damage after SARS-CoV-2 infection. Clin Gastroenterol Hepatol. 2020. https://doi.org/10.1016/j.cgh.2020.04.040.

218. de-Madaria E, Siau K, Cárdenas-Jaén K. Increased amylase and lipase in patients with COVID-19 pneumonia: don't blame the pancreas just yet! Gastroenterology. 2020. https://doi.org/10. 1053/j.gastro.2020.04.044.

219. Juhász MF, Ocskay K, Kiss S, Hegyi P, Párniczky A. Insufficient etiological workup of COVID-19-associated acute pancreatitis: a systematic review. World J Gastroenterol 2020;26:6270-6278. https://doi.org/10.3748/wjg.v26.i40.6270. 
220. Qin C, Zhou L, Hu Z, Zhang S, Yang S, Tao Y et al. Dysregulation of immune response in patients with COVID-19 in Wuhan, China. Clin Infect Dis. 2020. https://doi.org/10.1093/cid/ciaa2 48.

221. Singh AK, Jena A, Kumar-M P, Jha DK, Sharma V. Clinical presentation of COVID-19 in patients with inflammatory bowel disease: a systematic review and meta-analysis. Intest Res. 2021. https://doi.org/10.5217/ir.2020.00108.

222. Singh AK, Jena A, Kumar-M P, Sharma V, Sebastian S. Risk and outcomes of coronavirus disease (COVID-19) in patients with inflammatory bowel disease: a systematic review and metaanalysis. United Eur Gastroenterol J. 2020. https://doi.org/10. 1177/2050640620972602

223. Neurath MF. Covid-19 and immunomodulation in IBD. Gut. 2020. https://doi.org/10.1136/gutjnl-2020-321269.

224. Kennedy NA, Jones GR, Lamb CA, Appleby R, Arnott I, Beattie RM et al. British Society of Gastroenterology guidance for management of inflammatory bowel disease during the COVID19 pandemic. Gut 2020;69:984-990. https://doi.org/10.1136/ gutjnl-2020-321244.

225. Ungaro RC, Brenner EJ, Gearry RB, Kaplan GG, Kissous-Hunt M, Lewis JD et al. Effect of IBD medications on COVID-19 outcomes: results from an international registry. Gut 2021;70:725732. https://doi.org/10.1136/gutjnl-2020-322539.

226. Mårild $\mathrm{K}$, Fredlund $\mathrm{H}$, Ludvigsson JF. Increased risk of hospital admission for influenza in patients with celiac disease: a nationwide cohort study in Sweden. Am J Gastroenterol 2010;105:2465-2473. https://doi.org/10.1038/ajg.2010.352.

227. Siniscalchi M, Zingone F, Savarino EV, D’Odorico A, Ciacci C. COVID-19 pandemic perception in adults with celiac disease: an impulse to implement the use of telemedicine: COVID-19 and CeD. Dig Liver Dis. 2020. https://doi.org/10.1016/j.dld.2020.05. 014.

228. Monzani A, Lionetti E, Felici E, Fransos L, Azzolina D, Rabbone I et al. Adherence to the Gluten-Free diet during the lockdown for COVID-19 pandemic: a web-based survey of Italian subjects with celiac disease. Nutrients 2020;12:3467. https://doi.org/10. 3390/nu12113467.

229. Trovato CM, Montuori M, Cucchiara S, Oliva S. ESPGHAN "biopsy-sparing" guidelines for celiac disease in children with low antitransglutaminase during COVID-19. Eur J Gastroenterol Hepatol 2020;32:1523-1526. https://doi.org/10.1097/MEG. 0000000000001924.

230. Ghoneim S, Butt MU, Hamid O, Shah A, Asaad I. The incidence of COVID-19 in patients with metabolic syndrome and non-alcoholic steatohepatitis: a population-based study. Metabol Open. 2020;8:100057. https://doi.org/10.1016/j.metop.2020.100057.

231. Hu J, Wang Y. The clinical characteristics and risk factors of severe COVID-19. Gerontology. 2021. https://doi.org/10.1159/ 000513400

232. Hamid S, Alvares da Silva MR, Burak KW, Chen T, Drenth $\mathrm{JPH}$, Esmat G et al. WGO guidance for the care of patients with COVID-19 and liver disease. J Clin Gastroenterol 2021;55:1-11. https://doi.org/10.1097/MCG.0000000000001459.

233. Bhoori S, Rossi RE, Citterio D, Mazzaferro V. COVID-19 in long-term liver transplant patients: preliminary experience from an Italian transplant centre in Lombardy. Lancet Gastroenterol Hepatol 2020;5:532-533. https://doi.org/10.1016/S24681253(20)30116-3.

234. Colmenero J, Rodríguez-Perálvarez M, Salcedo M, Arias-Milla A, Muñoz-Serrano A, Graus J et al. Epidemiological pattern, incidence, and outcomes of COVID-19 in liver transplant patients. J Hepatol 2021;74:148-155. https://doi.org/10.1016/j. jhep.2020.07.040.

235. Gralnek IM, Hassan C, Beilenhoff U, Antonelli G, Ebigbo A, Pellisè $M$ et al. ESGE and ESGENA position statement on gastrointestinal endoscopy and the COVID-19 pandemic. Endoscopy 2020;52:483-490. https://doi.org/10.1055/a-1155-6229.

236. New York Society for Gastrointestinal Endoscopy. Guidelines for endoscopy units during the COVID-19 pandemic 2020. https:// www.nysge.org/Files/NYSGE\%20Guidelines\%20for\%20End oscopy\%20Units\%20During\%20the\%20COVID-19\%20Pan demic.pdf

237. Walsh CM, Fishman DS, Lerner DG. NASPGHAN Endoscopy and Procedures Committee Pediatric Endoscopy in the Era of Coronavirus disease 2019: A North American Society for pediatric gastroenterology, hepatology, and nutrition position paper. J Pediatr Gastroenterol Nutr 2020;70:741-750. https://doi.org/ 10.1097/MPG.0000000000002750.

238. Carvalho A, Alqusairi R, Adams A, Paul M, Kothari N, Peters $\mathrm{S}$ et al. SARS-CoV-2 gastrointestinal infection causing hemorrhagic colitis: implications for detection and transmission of COVID-19 disease. Am J Gastroenterol 2020;115:942-946. https://doi.org/10.14309/ajg.0000000000000667.

239. Ianiro G, Mullish BH, Kelly CR, Sokol H, Kassam Z, Ng S et al. Screening of faecal microbiota transplant donors during the COVID-19 outbreak: suggestions for urgent updates from an international expert panel. Lancet Gastroenterol Hepatol 2020;5:430-432. https://doi.org/10.1016/S2468-1253(20) 30082-0.

240. Cammarota G, Ianiro G, Kelly CR, Mullish BH, Allegretti $\mathrm{JR}$, Kassam $\mathrm{J}$ et al. International consensus conference on stool banking for faecal microbiota transplantation in clinical practice. Gut 2019;68:2111-2121. https://doi.org/10.1136/ gutjnl-2019-319548.

241. Ng SC, Chan FKL, Chan PKS. Screening FMT donors during the COVID-19 pandemic: a protocol for stool SARS-CoV-2 viral quantification. Lancet Gastroenterol Hepatol 2020;S24681253:30124-30132. https://doi.org/10.1016/S2468-1253(20) 30124-2.

242. Khanna S, Pardi D. Fecal microbiota transplantation for recurrent clostridioides difficile infection: the COVID-19 Era. Am J Gastroenterol 2020;115:971-974. https://doi.org/10.14309/ajg. 0000000000000689.

243. Chen W, Lan Y, Yuan X, Deng X, Li Y, Cai X et al. Detectable 2019-nCoV viral RNA in blood is a strong indicator for the further clinical severity. Emerg Microbes Infect 2020;9:469-473. https://doi.org/10.1080/22221751.2020.1732837.

244. Zhang J, Wang S, Xue Y. Fecal specimen diagnosis 2019 novel coronavirus-infected pneumonia. J Med Virol. 2020. https://doi. org/10.1002/jmv. 25742 .

245. Zhang W, Du RH, Li B, Zheng XS, Yang XL, Hu B, Wang YY et al. Molecular and serological investigation of 2019-nCoV infected patients: implication of multiple shedding routes. Emerg Microbes Infect 2020;9:386-389. https://doi.org/10.1080/22221 751.2020.1729071.

246. Wu J, Liu J, Li S, Peng Z et al. Detection and analysis of nucleic acid in various biological samples of COVID-19 patients. Travel Med Infect Dis. 2020;37:101673. https://doi.org/10.1016/j.tmaid. 2020.101673

247. Wang W, Xu Y, Gao R, Lu R, Han K, Wu G, Tan W. Detection of SARS-CoV-2 in different types of clinical specimens. JAMA. 2020;323:1843-1844. https://doi.org/10.1001/jama.2020.3786.

248. Lei C, Lin W, Deng X, Hu F et al. Factors associated with clinical outcomes in patients with Coronavirus disease 2019 in Guangzhou, China. J Clin Virol. 2020;133:104661. https://doi.org/10. 1016/j.jcv.2020.104661.

249. Peng D, Zhang J, Ji Y, Pan D. Risk factors for redetectable positivity in recovered COVID-19 children. Pediatr Pulmonol. 2020;55:3602-3609. https://doi.org/10.1002/ppul.25116.

250. Liu M, Li Q, Zhou J, Ai W et al. Value of swab types and collection time on SARS-COV-2 detection using RT-PCR assay. 
J Virol Methods. 2020;286:113974. https://doi.org/10.1016/j. jviromet.2020.113974.

251. Huang Y, Ding Z, Chen Q, Wu L et al. Environmental virus detection associated with asymptomatic SARS-CoV-2-infected individuals with positive anal swabs. Sci Total Environ 2021;753:142289. https://doi.org/10.1016/j. scitotenv.2020. 142289.

252. Li L, Liang Y, Hu F, Yan $\mathrm{H}$ et al. Molecular and serological characterization of SARS-CoV-2 infection among COVID-19 patients. Virology. 2020;551:26-35. https://doi.org/10.1016/j. virol.2020.09.008.

253. Peng L, Liu J, Xu W, Luo Q et al. SARS-CoV-2 can be detected in urine, blood, anal swabs, and oropharyngeal swabs specimens. J Med Virol. 2020;92:1676-1680. https://doi.org/10. 1002/jmv. 25936

254. Novazzi F, Cassaniti I, Piralla A, Di Sabatino A et al. SARSCoV-2 positivity in rectal swabs: implication for possible transmission. J Glob Antimicrob Resist 2020;22:754-755. https://doi.org/10.1016/j.jgar.2020.06.011.

255. Zhang X, Xue Y, Chen X, Wu JM et al. Effects of Tanreqing capsule on the negative conversion time of nucleic acid in patients with COVID-19: a retrospective cohort study. J Integr Med 2021;19:36-41. https://doi.org/10.1016/j.joim.2020.10. 002 .

256. Wu B, Lei ZY, Wu KL, He JR et al. Compare the epidemiological and clinical features of imported and local COVID-19 cases in Hainan, China. Infect Dis Poverty. 2020;9:143. https://doi.org/ 10.1186/s40249-020-00755-7.

257. Chen GQ, Luo WT, Zhao CH, Li CN et al. Comparison of clinical characteristics between fecal/perianal swab nucleic acid-positive and -negative patients with COVID-19. J Infect Dev Ctries. 2020;14:847-852. https://doi.org/10.3855/jidc.12885.

258. He Y, Luo J, Yang J, Song J et al. Value of viral nucleic acid in sputum and feces and specific $\operatorname{IgM} / \mathrm{IgG}$ in serum for the diagnosis of Coronavirus disease 2019. Front Cell Infect Microbiol. 2020;10:445. https://doi.org/10.3389/fcimb.2020.00445.

259. Lu Y, Li Y, Wang Y, Luo J, Yu W. Nucleic acid and antibody assay results in Chinese patients with coronavirus disease 2019 (COVID-19). Int Immunopharmacol. 2020;89:107089. https:// doi.org/10.1016/j.intimp.2020.107089.

260. Wang X, Zheng J, Guo L, Yao $\mathrm{H}$ et al. Fecal viral shedding in COVID-19 patients: clinical significance, viral load dynamics and survival analysis. Virus Res 2020;289:198147. https://doi. org/10.1016/j.virusres.2020.198147.

261. Shi D, Wu W, Wang Q, Xu K et al. Clinical characteristics and factors associated with long-term viral excretion in patients with severe acute respiratory syndrome coronavirus 2 infection: a single-center 28-day study. J Infect Dis 2020;222:910-918. https:// doi.org/10.1093/infdis/jiaa388.

262. Deng W, Guang TW, Yang M, Li JR et al. Positive results for patients with COVID-19 discharged form hospital in Chongqing, China. BMC Infect Dis 2020;20:429. https://doi.org/10.1186/ s12879-020-05151-y.

263. Lei Z, Cao H, Jie Y, Huang Z et al. A cross-sectional comparison of epidemiological and clinical features of patients with coronavirus disease (COVID-19) in Wuhan and outside Wuhan, China. Travel Med Infect Dis. 2020;35:101664. https://doi.org/10.1016/j. tmaid.2020.101664.

264. Lu X, Wang L, Sakthivel SK, Whitaker B et al. US CDC realtime reverse transcription PCR panel for detection of severe acute respiratory syndrome Coronavirus 2. Emerg Infect Dis. 2020;26:1654-1665. https://doi.org/10.3201/eid2608.201246.

265. Shang H, Bai T, Chen Y, Huang C et al. Outcomes and implications of diarrhea in patients with SARS-CoV-2 infection. Scand J Gastroenterol 2020;55:1049-1056. https://doi.org/10.1080/ 00365521.2020 .1800078 .
266. Han MS, Seong MW, Kim N, Shin S et al. Viral rna load in mildly symptomatic and asymptomatic children with COVID19, Seoul, South Korea. Emerg Infect Dis 2020;26:2497-2499. https://doi.org/10.3201/eid2610.202449.

267. Xu T, Wang J, Hu B, Zhang G et al. Identification of the RNasebinding site of SARS-CoV-2 RNA for anchor primer-PCR detection of viral loading in 306 COVID-19 patients. Brief Bioinform 2020;16:193. https://doi.org/10.1093/bib/bbaa193.

268. Han C, Duan C, Zhang S, Spiegel B et al. Digestive symptoms in COVID-19 patients with mild disease severity: clinical presentation, stool viral RNA testing, and outcomes. Am J Gastroenterol. 2020;115:916-923. https://doi.org/10.14309/ajg.0000000000 000664.

269. Lin W, Xie Z, Li Y, Li L, Wen C et al. Association between detectable SARS-COV-2 RNA in anal swabs and disease severity in patients with coronavirus disease 2019. J Med Virol 2021;93:794-802. https://doi.org/10.1002/jmv.26307.

270. Wei XS, Wang X, Niu YR, Ye LL et al. Diarrhea is associated with prolonged symptoms and viral carriage in Corona virus disease 2019. Clin Gastroenterol Hepatol. 2020;18:1753-1759.e2. https://doi.org/10.1016/j.cgh.2020.04.030.

271. Ling Y, Xu SB, Lin YX, Tian D et al. Persistence and clearance of viral RNA in 2019 novel coronavirus disease rehabilitation patients. Chin Med J (Engl). 2020;133:1039-1043. https://doi. org/10.1097/CM9.0000000000000774.

272. Turriziani O, Sciandra I, Mazzuti L, Di Carlo D et al. SARSCoV-2 diagnostics in the virology laboratory of a University Hospital in Rome during the lockdown period. J Med Virol 2021;93:886-891. https://doi.org/10.1002/jmv.26332.

273. Jiehao C, Jin X, Daojiong L, Zhi Y et al. A case series of children with 2019 novel coronavirus infection: clinical and epidemiological features. Clin Infect Dis 2020;71:1547-1551. https://doi.org/ 10.1093/cid/ciaa198.

274. Yin S, Peng Y, Ren Y, Hu M et al. The implications of preliminary screening and diagnosis: clinical characteristics of 33 mild patients with SARS-CoV-2 infection in Hunan, China. $J$ Clin Virol 2020;128:104397. https://doi.org/10.1016/j.jcv.2020. 104397.

275. Clinical and virologic characteristics of the first 12 patients with coronavirus disease 2019 (COVID-19) in the United States. Nat Med. 2020;26:861-868. https://doi.org/10.1038/ s41591-020-0877-5

276. Sun J, Xiao J, Sun R, Tang X et al. Prolonged persistence of SARS-CoV-2 RNA in body fluids. Emerg Infect Dis 2020;26:1834-1838. https://doi.org/10.3201/eid2608.201097.

277. Kim JM, Kim HM, Lee EJ, Jo HJ et al. Detection and isolation of SARS-CoV-2 in serum, urine, and stool specimens of COVID-19 patients from the Republic of Korea. Osong Public Health Res Perspect 2020;11:112-117. https://doi.org/10.24171/j.phrp.2020. 11.3.02.

278. Young BE, Ong SWX, Kalimuddin S, Low JG, et al. Singapore 2019 novel Coronavirus outbreak research team. epidemiologic features and clinical course of patients infected with SARSCoV-2 in Singapore. JAMA 2020;323:1488-1494. https://doi. org/10.1001/jama.2020.3204.

279. Mesoraca A, Margiotti K, Viola A, Cima A et al. Evaluation of SARS-CoV-2 viral RNA in fecal samples. Virol J 2020;17:86. https://doi.org/10.1186/s12985-020-01359-1.

280. Du W, Yu J, Liu X, Chen $\mathrm{H}$ et al. Persistence of SARS-CoV-2 virus RNA in feces: a case series of children. $J$ Infect Public Health. 2020;13:926-931. https://doi.org/10.1016/j.jiph.2020. 05.025 .

281. Zhou H, Zhu L, Leng Y, Wang D et al. Clinical and imaging findings of discharged patients with SARS-CoV-2 positive anal swab samples: a descriptive study. BMC Infect Dis. 2020;20:644. https://doi.org/10.1186/s12879-020-05363-2. 
282. Van Doorn AS, Meijer B, Frampton CMA, Barclay ML, de Boer NKH. Systematic review with meta-analysis: SARS-CoV-2 stool testing and the potential for faecal-oral transmission. Aliment Pharmacol Ther 2020;52:1276-1288. https://doi.org/10.1111/ apt.16036.

283. Hanada S, Pirzadeh M, Carver KY, Deng JC. Respiratory viral infection-induced microbiome alterations and secondary bacterial pneumonia. Front Immunol 2018;9:2640. https://doi.org/10. 3389/fimmu.2018.02640.

284. Gu S, Chen Y, Wu Z, Chen Y, Gao H, Lv L et al. Alterations of the Gut microbiota in patients with COVID-19 or H1N1 influenza. Clin Infect Dis. 2020. https://doi.org/10.1093/cid/ciaa709.
285. Zuo T, Zhang F, Lui GCY, Yeoh YK, Li AYL, Zhan H et al. Alterations in Gut microbiota of patients with COVID-19 during time of hospitalization. Gastroenterology 2020;159:944-955.e8. https://doi.org/10.1053/j.gastro.2020.05.048.

Publisher's Note Springer Nature remains neutral with regard to jurisdictional claims in published maps and institutional affiliations.

\section{Authors and Affiliations}

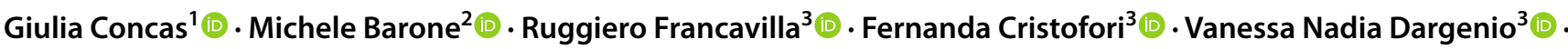

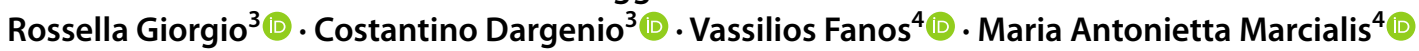

Giulia Concas

giulia.concas90@tiscali.it

Ruggiero Francavilla

ruggiero.francavilla@uniba.it

Fernanda Cristofori

fernandacristofori@gmail.com

Vanessa Nadia Dargenio

vane.nadia@gmail.com

Rossella Giorgio

r.giorgio@gmail.com

Costantino Dargenio

costy.dargenio@gmail.com

Vassilios Fanos

vfanos@aoucagliar.it
Maria Antonietta Marcialis

mariaantoniettamarcialis@ aoucagliari.it

1 School of Paediatrics, University of Cagliari, 09124 Cagliari, Italy

2 Gastroenterology Unit, Department of Emergency and Organ Transplantation, University of Bari, University Hospital "Policlinico", Piazza G. Cesare 11, 70124 Bari, Italy

3 Department of Biomedical Science and Human Oncology, Children's Hospital "Giovanni XXIII", University of Bari, 70126 Bari, Italy

4 Neonatal Intensive Care Unit, Azienda Ospedaliero Universitaria, University of Cagliari, Cagliari, 09124 Cagliari, Italy 